\title{
A bottom-up quantification of foliar mercury uptake fluxes across Europe
}

\author{
Lena Wohlgemuth ${ }^{1}$, Stefan Osterwalder ${ }^{2}$, Carl Joseph $^{1}$, Ansgar Kahmen ${ }^{1}$, Günter Hoch ${ }^{1}$, Christine Alewell ${ }^{1}$, and \\ Martin Jiskra ${ }^{1}$ \\ ${ }^{1}$ Department of Environmental Sciences, University of Basel, Basel, Switzerland \\ ${ }^{2}$ Université Grenoble Alpes, CNRS, IRD, Grenoble INP, Institut des Géosciences de l'Environnement, Grenoble, France
}

Correspondence: Lena Wohlgemuth (lena.wohlgemuth@unibas.ch) and Martin Jiskra (martin.jiskra@unibas.ch)

Received: 24 July 2020 - Discussion started: 26 August 2020

Revised: 30 October 2020 - Accepted: 4 November 2020 - Published: 21 December 2020

\begin{abstract}
The exchange of gaseous elemental mercury, $\operatorname{Hg}(0)$, between the atmosphere and terrestrial surfaces remains poorly understood mainly due to difficulties in measuring net $\mathrm{Hg}(0)$ fluxes on the ecosystem scale. Emerging evidence suggests foliar uptake of atmospheric $\mathrm{Hg}(0)$ to be a major deposition pathway to terrestrial surfaces. Here, we present a bottom-up approach to calculate $\mathrm{Hg}(0)$ uptake fluxes to aboveground foliage by combining foliar $\mathrm{Hg}$ uptake rates normalized to leaf area with species-specific leaf area indices. This bottom-up approach incorporates systematic variations in crown height and needle age. We analyzed $\mathrm{Hg}$ content in 583 foliage samples from six tree species at 10 European forested research sites along a latitudinal gradient from Switzerland to northern Finland over the course of the 2018 growing season. Foliar $\mathrm{Hg}$ concentrations increased over time in all six tree species at all sites. We found that foliar $\mathrm{Hg}$ uptake rates normalized to leaf area were highest at the top of the tree crown. Foliar $\mathrm{Hg}$ uptake rates decreased with needle age of multiyear-old conifers (spruce and pine). Average species-specific foliar $\mathrm{Hg}$ uptake fluxes during the 2018 growing season were $18 \pm 3 \mathrm{\mu g} \mathrm{Hg} \mathrm{m}^{-2}$ for beech, $26 \pm 5 \mu \mathrm{g} \mathrm{Hg} \mathrm{m}^{-2}$ for oak, $4 \pm 1 \mu \mathrm{g} \mathrm{Hg} \mathrm{m}^{-2}$ for pine and $11 \pm 1 \mu \mathrm{g} \mathrm{Hg} \mathrm{m}^{-2}$ for spruce. For comparison, the average $\mathrm{Hg}$ (II) wet deposition flux measured at 5 of the 10 research sites during the same period was $2.3 \pm 0.3 \mu \mathrm{g} \mathrm{Hg} \mathrm{m}^{-2}$, which was 4 times lower than the site-averaged foliar uptake flux of $10 \pm 3 \mu \mathrm{g} \mathrm{Hg} \mathrm{m}^{-2}$. Scaling up site-specific foliar uptake rates to the forested area of Europe resulted in a total foliar $\mathrm{Hg}$ uptake flux of approximately $20 \pm 3 \mathrm{Mg}$ during the 2018 growing season. Considering that the same flux applies to the global land area of temperate forests, we estimate
\end{abstract}

a foliar $\mathrm{Hg}$ uptake flux of $108 \pm 18 \mathrm{Mg}$. Our data indicate that foliar Hg uptake is a major deposition pathway to terrestrial surfaces in Europe. The bottom-up approach provides a promising method to quantify foliar $\mathrm{Hg}$ uptake fluxes on an ecosystem scale.

\section{Introduction}

Mercury $(\mathrm{Hg})$ is a toxic pollutant ubiquitous in the environment due to long-range atmospheric transport. Anthropogenic emissions of $\mathrm{Hg}$ into the atmosphere mainly originate from burning of coal, artisanal and small-scale gold mining, and nonferrous metal and cement production, while geogenic emissions occur from volcanoes and rock weathering (UN Environment, 2019). Atmospheric Hg is deposited to terrestrial surfaces and the ocean and can be re-emitted back to the atmosphere (Bishop et al., 2020; Obrist et al., 2018). The residence time of $\mathrm{Hg}$ in the atmosphere and its transfer to land and ocean surfaces mainly depends on its speciation (Driscoll et al., 2013). Gaseous elemental mercury $\mathrm{Hg}(0)$ is the dominant form $(>90 \%$ ) of atmospheric $\mathrm{Hg}$ (Sprovieri et al., 2017), exhibiting a residence time of several months to more than a year (Ariya et al., 2015; Saiz-Lopez et al., 2018). Atmospheric Hg will ultimately be transferred to water and land surfaces by wet or dry deposition. In the wet deposition process, $\mathrm{Hg}(0)$ is oxidized in the atmosphere to water-soluble $\mathrm{Hg}$ (II) and washed down to the Earth surface by precipitation (Driscoll et al., 2013). Wet deposition fluxes of $\mathrm{Hg}(\mathrm{II})$ to terrestrial surfaces are well constrained and direct measurements are coordinated in regional and interna- 
tional atmospheric deposition monitoring programs (EMEP, NADP) (EMEP, 2016; Prestbo and Gay, 2009; Wängberg et al., 2007; Weiss-Penzias et al., 2016).

Dry deposition fluxes of $\mathrm{Hg}(0)$ and $\mathrm{Hg}(\mathrm{II})$ to the Earth surface are less constrained owing to challenges in measuring net ecosystem exchange fluxes (Driscoll et al., 2013; Zhang et al., 2009) and atmospheric $\mathrm{Hg}$ (II) concentrations (Jaffe et al., 2014). The dry deposition of $\mathrm{Hg}$ can occur by vegetation uptake and subsequent transfer to the ground via litterfall (Risch et al., 2017; Wang et al., 2016), by wash-off from foliar surfaces via throughfall (Wright et al., 2016) or by direct deposition to terrestrial surfaces and soils (Obrist et al., 2014). Hg dry deposition is usually not routinely monitored, with the $\mathrm{Hg}$ litterfall monitoring network of NADP being a notable exception (Risch et al., 2012, 2017). Consequently, atmospheric mercury models inferring Hg dry deposition across Europe during summer months lack observational constraints (Gencarelli et al., 2015). Ecosystem-scale mass balance studies, however, revealed that litterfall deposition to forest floors exceeds wet deposition (Bushey et al., 2008; Demers et al., 2007; Graydon et al., 2006; Grigal, 2002; Rea et al., 2002; Risch et al., 2012, 2017; St. Louis et al., 2001; Teixeira et al., 2012; Zhang et al., 2016). Several lines of evidence suggest that uptake of atmospheric $\mathrm{Hg}(0)$ by vegetation represents an important process in terrestrial Hg cycling: (i) isotopic fingerprinting studies revealed that approximately $90 \%$ of $\mathrm{Hg}$ in foliage and $60 \%-90 \%$ of $\mathrm{Hg}$ in soils originate from atmospheric $\mathrm{Hg}(0)$ uptake by vegetation (Demers et al., 2013; Enrico et al., 2016; Jiskra et al., 2015; Zheng et al., 2016); (ii) observations of foliar Hg concentrations increase with exposure time to atmospheric $\mathrm{Hg}(0)$ (Assad et al., 2016; Ericksen and Gustin, 2004; Fleck et al., 1999; Frescholtz et al., 2003; Laacouri et al., 2013; Millhollen et al., 2006; Rea et al., 2002), while Hg uptake via the root system was found to be minor (Assad et al., 2016; Frescholtz et al., 2003; Millhollen et al., 2006); and (iii) atmospheric $\mathrm{Hg}(0)$ correlates with the photosynthetic activity of vegetation, suggesting that summertime minima in atmospheric $\mathrm{Hg}(0)$ in the Northern Hemisphere are controlled by vegetation uptake (Jiskra et al., 2018; Obrist, 2007).

The exact mechanism of the atmosphere-foliar $\mathrm{Hg}(0)$ exchange is not yet fully understood. Laacouri et al. (2013) observed highest $\mathrm{Hg}$ concentrations in leaf tissues as opposed to leaf surfaces and cuticles, implying that $\mathrm{Hg}(0)$ diffuses into the leaves. By exposing plants to $\mathrm{Hg}(0)$ in the form of enriched Hg isotope tracers, Rutter et al. (2011) found that plant $\mathrm{Hg}$ uptake was mainly to the leaf interior. Leaf $\mathrm{Hg}$ content correlated with stomatal density (Laacouri et al., 2013), suggesting that stomatal uptake represents the main pathway. Nonstomatal uptake was observed by Stamenkovic and Gustin (2009) under conditions of reduced stomatal aperture, implying adsorption of atmospheric $\mathrm{Hg}$ to cuticles surfaces. Re-emission of $\mathrm{Hg}$ from foliage can occur by photoreduction of $\mathrm{Hg}(\mathrm{II})$ to $\mathrm{Hg}(0)$ and subsequent volatilization (Graydon et al., 2006). The re-emission potential of $\mathrm{Hg}$ previously taken up by foliage and strongly complexed in plant tissue (Manceau et al., 2018) was suggested to be lower than the reemission potential of surface-bound $\mathrm{Hg}$ (Jiskra et al., 2018; Yuan et al., 2019).

$\mathrm{Hg}$ contents in foliage were shown to be species specific (Blackwell and Driscoll, 2015; Laacouri et al., 2013; Navrátil et al., 2016; Obrist et al., 2012; Rasmussen et al., 1991). It is currently unresolved if deciduous broad leaves accumulate higher $\mathrm{Hg}$ concentrations than needles (Blackwell and Driscoll, 2015; Navrátil et al., 2016) or if it is the other way around (Hall and St. Louis, 2004; Obrist et al., 2011, 2012). Deciduous species shed their leaves at the end of the growing season, whereas most conifers grow needles over multiple years and continue to accumulate $\mathrm{Hg}$, resulting in increasing $\mathrm{Hg}$ concentrations with needle age (Hutnik et al., 2014; Navrátil et al., 2019; Ollerova et al., 2010). Furthermore, $\mathrm{Hg}$ concentrations in foliage have been shown to vary within the canopy (Bushey et al., 2008). Physiological differences between deciduous and coniferous tree species and inconsistent sampling of needle age and canopy height may have contributed to the uncertainty in literature of whether deciduous or coniferous species take up more $\mathrm{Hg}$.

The goal of this study was to improve the understanding of foliar $\operatorname{Hg}(0)$ uptake and quantify foliar uptake fluxes at European forest research sites. The objectives were to (1) determine the temporal evolution of $\mathrm{Hg}$ concentrations and the $\mathrm{Hg}$ pool in foliage of six tree species at 10 European research sites along a south-north transect from Switzerland to Finland over the 2018 growing season; (2) investigate the effect of needle age, crown height and tree functional group on foliar $\mathrm{Hg}$ uptake; (3) quantify foliar $\mathrm{Hg}$ uptake fluxes per square meter of ground surface area based on the temporal evolution of the foliar $\mathrm{Hg}$ pool over the growing season; and (4) estimate the foliar uptake fluxes for Europe and temperate forests globally by scaling up species-averaged foliar uptake rates determined in this study to respective forest areas.

\section{Materials and methods}

\subsection{Site description}

Foliage samples were collected from 10 European research sites located along a south-north transect from Switzerland to Scandinavia (Fig. 1). The Hölstein site in Switzerland comprises the Swiss Canopy Crane II (SCCII) operated by the Physiological Plant Ecology Group of the University of Basel (Kahmen et al., 2019). Our principal site, Hölstein, allowed us to systematically access the entire canopy through the gondola of a crane. The research sites Schauinsland and Schmücke are part of the air monitoring network of the German Environment Agency (UBA) (Schleyer et al., 2013). Hyltemossa, Norunda, Svartberget and Pallas are Integrated Carbon Observation System (ICOS) sites operated by Lund University (LU), the Swedish University of Agricultural Sci- 


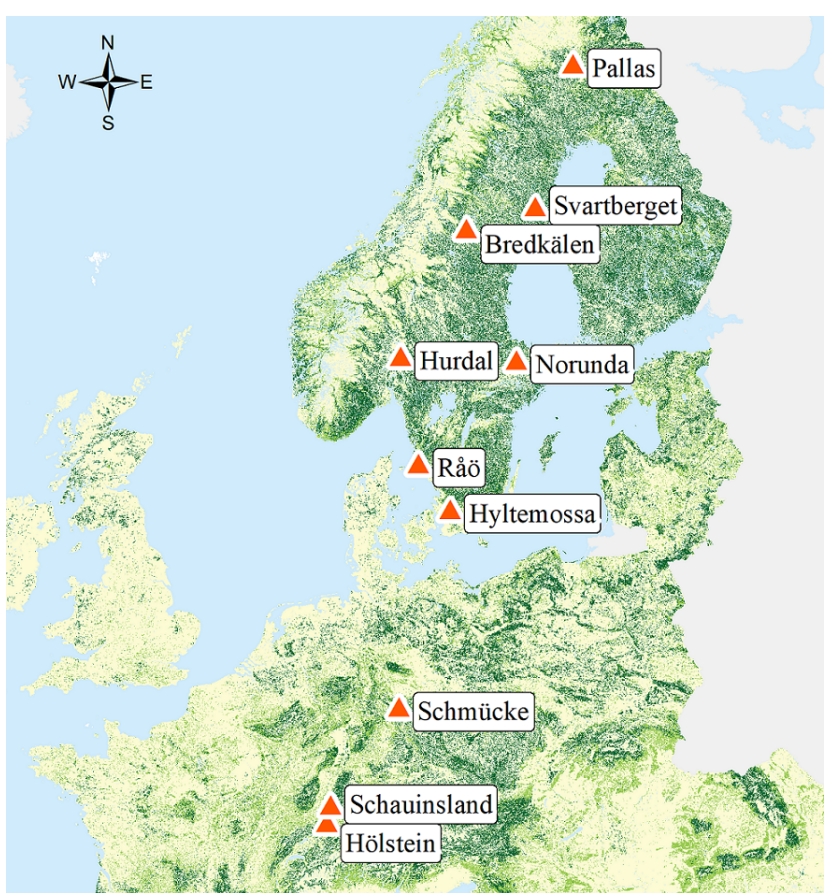

Figure 1. Research sites for foliage sampling during the 2018 growing season. Base map corresponds to the Joint Research Centre (JRC) Pan-European Forest Type Map 2006 (JRC, 2010; Kempeneers et al., 2011). Reuse is authorized under reuse policy of the European Commission (EU, 2011).

ences (SLU) and the Finnish Meteorological Institute (FMI) (Lindroth et al., 2015, 2018; Lohila et al., 2015). Hurdal is a prospective ICOS ecosystem station, an ICP Forests Level II Plot and a European Monitoring and Evaluation Programme (EMEP) air measurement site operated by the Norwegian Institute of Bioeconomy Research (NIBIO) and the Norwegian Institute for Air Research (NILU) (Lange, 2017). Bredkälen and Råö are Swedish EMEP air measurement sites operated by the Swedish Environmental Research Institute (IVL) (Wängberg et al., 2016; Wängberg and Munthe, 2001). Tree species composition differed among sites. Hölstein, for instance, is a mixed forest harboring 14 different tree species, while Hyltemossa is an exclusive spruce stand (see Table S6 for details).

\subsection{Sample collection}

Foliage sampling strategy was guided by the ICP Forests sampling manual (Rautio et al., 2016), requesting to take samples that have developed under open sunlight from the top third of the crown canopy. At four sites (Svartberget, Hyltemossa, Norunda and Hölstein), we complied with the ICP Forest sampling protocol. At six sites (Pallas, Bredkälen, Hurdal, Råö, Schmücke and Schauinsland), we had to adapt the sampling strategy to local conditions and available equipment. At our focus research site in Hölstein, Switzerland, a crane allowed access to the top of the crown and vertical sampling of beech, oak and spruce. Since pine did not grow needles at ground level, we did not sample their vertical profiles. Vertical sampling of spruce needles in Hölstein during 2018 was repeated in 2019 with five spruce trees, because only two spruce trees had been sampled during 2018 of which one died from drought-induced stress by the end of the 2018 growing season (Schuldt et al., 2020). The relative effect of height on $\mathrm{Hg}$ accumulation in Hölstein spruce needles is therefore investigated with data from the growing season 2019. Samples at Hyltemossa and Svartberget were cut from tree canopies using a $20 \mathrm{~m}$ telescopic scissors and at Hurdal using a $3 \mathrm{~m}$ telescopic scissors. At Norunda samples were shot from the tree canopies using a shotgun. At Schauinsland, Schmücke, Råö and Bredkälen, we used a $5 \mathrm{~m}$ telescopic scissors for cutting the branches in the lower half of the crown. At Pallas and Råö branches were cut from low-growing trees at breast height. We collected intact leaves at three to six time points during the 2018 growing season. Samples from at least three different branches of the same tree were pooled to a composite sample. We sampled at least three trees per species (one to four species) with the exception of Råö where only one oak and one spruce tree were available. Sampling and sample preparation were conducted using clean nitryl gloves. Leaves were cut from outermost branches. All samples were stored in ziplock bags in the freezer until analysis. Sampling dates are reported in Table S1 for each site. At Hölstein atmospheric $\operatorname{Hg}(0)$ was measured integrated over the whole sampling period by using passive air samplers (PASs) as described by McLagan et al. (2016). PASs were exposed at ground level $(1.6 \mathrm{~m})$ under the canopy at four locations on the plot and additionally at three heights of 10, 19 and $35 \mathrm{~m}$ on the crane railing (details in Sect. S7 and Fig. S4) from 15 May 2018 to 18 October 2018. The PAS air measurement campaign at Hölstein was repeated in 2019 with PASs exposed at 1.5, 10,19 and $35 \mathrm{~m}$ height at the crane from 16 May 2019 to 12 September 2019. Measurements of one of the PAS installed at $10 \mathrm{~m}$ height in 2019 were excluded from further analysis, because they produced an implausibly high result which can probably be traced back to a measurement error. Under dry conditions at noontime on 17 July 2019 we measured stomatal conductance to water vapor of beech, pine and oak from the crane gondola at Hölstein using an SC1 leaf porometer (Meter Group, Inc. USA). At five locations (Schauinsland, Schmücke, Råö, Bredkälen and Pallas) Hg(II) wet deposition measurements were performed by the operators of the research sites. At Schauinsland and Schmücke, Eigenbrodt NSA 181/KD (Eigenbrodt GmbH, Königsmoor, Germany) samplers were employed for collecting samples, and total $\mathrm{Hg}$ was measured using atomic fluorescence spectroscopy (see UBA, 2004, for details on analysis). At Råö, Bredkälen and Pallas wet deposition was sampled according to EMEP protocol (NILU, 2001) (refer to Torseth et al., 2012, for an overview of EMEP). 


\subsection{Sample preparation and measurements}

In total 584 leaf samples were collected, weighted and analyzed for leaf mass per area (LMA) and subsequently dried and ground for $\mathrm{Hg}$ concentration analysis. The projected leaf area was measured using a LI3100 area meter (LI-COR Biosciences, USA). We performed duplicate scans of $17 \%$ of foliage samples and obtained a mean percent deviation between scans and respective duplicate scans of $3 \% \pm 3 \%$. For measuring projected needle area, we calibrated the LI3100 with rubberized wires of known length and a diameter of $1.74 \pm 0.02 \mathrm{~mm}$ (see Sect. S4 and Fig. S2). For the two sites Hurdal and Pallas, the performance and resolution of the LI3100 was insufficient and unrealistic results were discarded, and median values from literature were used instead (see Sect. S4 for details). For the three ICOS sites Hyltemossa, Norunda and Svartberget, we obtained LMA values measured by research staff according to ICOS protocol (Loustau et al., 2018; Sect. S4). Foliage samples were oven-dried at $60^{\circ} \mathrm{C}$ for $24 \mathrm{~h}$. We did not observe any $\mathrm{Hg}$ losses irrespective of drying temperatures of 25,60 or $105^{\circ} \mathrm{C}$ (Fig. S1). A similar result was obtained by Yang et al. (2017) for $\mathrm{Hg}$ in wood and by Lodenius et al. (2003) for $\mathrm{Hg}$ in moss. Dried samples were weighted and homogenously ground in an ordinary stainless-steel coffee grinder. Total Hg concentrations were measured with atomic absorption spectrophotometry using a direct mercury analyzer (DMA-80, Heerbrugg, Switzerland). Standard Reference Materials (SRMs) used in this study were NIST-1515 apple leaves and spruce needle sample B from the 19th ICP Forests needle/leaf interlaboratory comparison. Standard measurement procedures included running a quality-control pre-sequence consisting of three method blanks, one process blank (wheat flour) and three liquid primary reference standards (PRSs; $50 \mathrm{mg}$ of $100 \mathrm{ng} \mathrm{g}^{-1}$ NIST-3133 in $1 \% \mathrm{BrCl}$ ). Daily performance of the instrument was assessed based on the three liquid PRSs and all data were corrected accordingly if the measured PRSs were within $90 \%$ to $110 \%$ of the expected value. If PRSs were outside this acceptable range, the instrument was recalibrated. Each sequence consisted of four SRMs, one process blank consisting of commercial wheat flour and 35 samples. Sequences were rejected if one SRM value was outside of the certified uncertainty range (NIST-1515) or $10 \%$ of the respective target concentration (ICP Forests spruce B) or if the absolute $\mathrm{Hg}$ content of the flour blank was $>0.3 \mathrm{ng}$. The average recovery for $\mathrm{Hg}$ during measurement of all samples in this study was $99.9 \% \pm 4.0 \%$ (mean $\pm \mathrm{SD})(n=15)$ for NIST- 1515 and $101.6 \% \pm 6.9 \%$ (mean \pm SD) $(n=40)$ for ICP Forests spruce B. The process blanks exhibited an average $\mathrm{Hg}$ content of $0.10 \mathrm{ng} \pm 0.09 \mathrm{ng}$ (mean $\pm \mathrm{SD})(n=23)$. As an additional quality control, we passed the 21 st and 22nd ICP Forests needle/leaf interlaboratory comparison test 2018/2019 and 2019/2020 for $\mathrm{Hg}$.

\subsection{Bottom-up calculation of foliar $\mathrm{Hg}$ uptake fluxes}

Foliar $\mathrm{Hg}$ concentration $\left(\mu \mathrm{g} \mathrm{Hg} \mathrm{g}_{\text {d.w. }}^{-1}\right.$ ) of each leaf/needle sample was multiplied with the respective sample leaf mass per area (LMA; $g_{\text {d.w. }} \mathrm{m}_{\text {leaf }}^{-2}$ ) to obtain foliar $\mathrm{Hg}$ content normalized to leaf area $\left(\mu \mathrm{g} \mathrm{Hg} \mathrm{m}_{\text {leaf }}^{-2}\right.$ ). Foliar $\mathrm{Hg}$ uptake rates (uptake $R_{\text {leaf area }} ; \mu \mathrm{g} \mathrm{Hg} \mathrm{m}$ leaf $^{-2}$ month $^{-1}$ ) for each tree species were derived from the change in $\mathrm{Hg}$ content normalized to leaf area over time (three to six points in time) using a linear regression fit. Linear regression was performed by applying an ordinary least square model in the Python module statsmodels (Python 3.7.0). Linear regression parameters $\left(R^{2}\right)$ of each site and tree species are summarized in Table S1. Foliar $\mathrm{Hg}$ uptake fluxes (uptake $F_{\text {ground area }}$; $\mu \mathrm{g} \mathrm{Hg} \mathrm{m} \mathrm{mgund}_{\text {ground }}^{-2}$ month $^{-1}$ ) per ground surface area were calculated by multiplying the foliar $\mathrm{Hg}$ uptake rates (uptake $R_{\text {leaf area }}$ ) with species-specific leaf area indices (LAIs; $\mathrm{m}_{\text {leaf }}^{2} \mathrm{~m}_{\text {ground }}^{-2}$ ) in order to obtain foliar $\mathrm{Hg}$ uptake fluxes normalized to ground surface area:

uptake $F_{\text {ground area }}=$ uptake $R_{\text {leaf area }} \times$ LAI.

Figure 2 illustrates this flux calculation schematically. We used species-specific LAIs retrieved from a global database provided by Iio and Ito (2014). In total, 205 values of onesided LAIs measured in central Europe and Scandinavia between latitudes of 46 and $63^{\circ} \mathrm{N}$ and published in peerreviewed journals were selected for calculating an average LAI value of each species. Species-specific average LAI values are displayed in Table S2. All LAI values for each species are peak-season values. To calculate the foliar uptake flux over the growing season, the average daily uptake flux was multiplied by the length of the growing season in days. For each site, the growing season length in days, which depends on the latitude of the site, was obtained from Garonna et al. (2014) and Rötzer and Chmielewski (2001) (Table S1). The approximate relative abundance of sampled tree species (Table S6) at the four research sites Hölstein, Hyltemossa, Norunda and Svartberget were obtained by research staff (Irene Lehner, André Kühne, and Per Marklund, personal communication, 2019). We calculated the total foliar Hg uptake flux for these four research sites as the sum of speciesspecific foliar $\mathrm{Hg}$ uptake fluxes of all locally dominant tree species multiplied by their relative abundance (Table S6).

\subsection{Correction factor for needle $\mathrm{Hg}$ uptake flux as a function of needle age}

At all sites, we investigated $\mathrm{Hg}$ concentrations in multiyear pine and spruce needles from the current-season ( $y_{0}$ needles sprouting in spring of the sampling year) and in 1-yearold needles $\left(y_{1}\right.$, needles sprouting in the year prior to the sampling year). At five sites (Bredkälen, Hölstein, Hyltemossa, Schauinsland and Schmücke), we additionally sampled 2-year-old $\left(y_{2}\right)$ and 3-year-old $\left(y_{3}\right)$ spruce needles. Sampling and measuring $\mathrm{Hg}$ uptake in all needle age classes of a 
Seasonal $\mathrm{Hg}$ concentration increase per leaf area $\quad \times \quad$ Leaf area over ground area
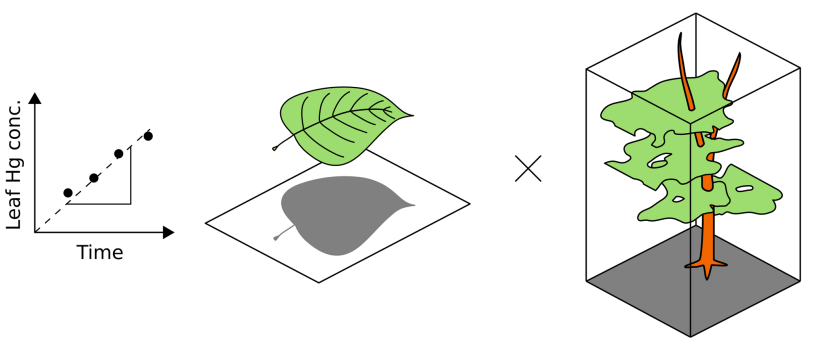

Figure 2. Bottom-up approach, (Eq. 1), for calculating foliar $\mathrm{Hg}$ uptake flux per ground area (uptake $F ; n g \mathrm{Hg} \mathrm{m}_{\text {ground }}^{-2}$ month $^{-1}$ ). The linear regression slope of leaf $\mathrm{Hg}$ concentration $\left(\mathrm{ng} \mathrm{Hg} \mathrm{g}_{\mathrm{d.w}}^{-1}\right)$ over time is multiplied with the respective sample leaf mass per area (LMAs; $g_{\text {d.w. }} \mathrm{m}_{\text {leaf }}^{-2}$ ). The resulting foliar $\mathrm{Hg}$ uptake rate per leaf area (uptake $R_{\text {leaf area }}$; $\mathrm{ng} \mathrm{Hg} \mathrm{m}_{\text {leaf }}^{-2}$ month $^{-1}$ ) is then multiplied with the species-specific leaf area index (LAI; $\mathrm{m}_{\text {leaf }}^{2} \mathrm{~m}_{\text {ground }}^{-2}$ ).

conifer tree is a time-consuming and costly process. In standard forest monitoring programs, young needles from age class $y_{0}$ or $y_{1}$ are usually sampled. We determined a speciesspecific age correction factor $\left(\mathrm{cf}_{\text {age }}\right)$ to relate the needle uptake of an entire coniferous tree to the current-season $\left(y_{0}\right)$ needles. The factor, $\mathrm{cf}_{\text {age }}$, was derived from $\mathrm{Hg}$ measurements of 316 needle samples of different age classes using (i) the evaluated relative $\mathrm{Hg}$ accumulation rate (RAR; Eq. 2), which represents the $\mathrm{Hg}$ accumulation of each needle age class normalized to the $\mathrm{Hg}$ accumulation rate in current season $\left(y_{0}\right)$, and (ii) the respective relative biomass (RB) of each needle age class to the total needle biomass from literature determined by Matyssek et al. (1995). Needles used to determine the RAR were sampled by the Bavarian State Institute of Forestry at 11 ICP Forests plots in Bavaria, Germany, in 2015 and 2017. Needle samples from 2015 consisted of 33 batches of spruce and 6 batches of pine samples. Needle samples from 2017 consisted of 32 batches of spruce and 6 batches of pine samples. For spruce needles, each batch was composed of samples of age class $y_{0}$ to age class $y_{3}$, of which seven spruce needle batches were composed of samples of age classes $y_{0}$ to $y_{5}$ and six spruce needle batches of age classes $y_{0}$ to $y_{6}$. For pine needles, each batch of the two sampling years 2015 and 2017 was composed of samples of age classes $y_{0}$ to $y_{1}$ and one pine needle batch was additionally composed of samples of age class $y_{2}$. The RAR of spruce and pine samples of different needle years $\left(y_{i}, i=1,2, \ldots, n\right)$ in each sample batch of the sampling years 2015 and 2017 was calculated as follows:

$\operatorname{RAR}_{y_{i}}=\frac{\mathrm{c}_{\mathrm{Hg}}\left(y_{i}\right)-\mathrm{c}_{\mathrm{Hg}}\left(y_{i-1}\right)}{\mathrm{c}_{\mathrm{Hg}}\left(y_{0}\right)}$

Resulting average RARs of the spruce and pine needle samples together with the RB are presented in Table S3. For each needle age class, the factor $\mathrm{cf}_{\text {age }}$ calculates as

$c_{\text {age }}=1 \times \mathrm{RB}_{y_{0}}+\mathrm{RAR}_{y_{1}} \times \mathrm{RB}_{y_{1}}+\ldots+\mathrm{RAR}_{y_{n}} \times \mathrm{RB}_{y_{n}}$.

In accordance with our bottom-up approach for calculating the foliar Hg uptake flux (Eq. 1), the modified flux calculation for conifers is

uptake $F_{\text {ground area }}=\mathrm{cf}_{\text {age }} \times$ uptake $R_{y 0 \text {; needle area }} \times$ LAI.

Final values of $\mathrm{cf}_{\text {age }}$ are summarized in Sect. S6 and Table S3.

\subsection{Correction factor for foliar Hg uptake flux as a function of crown height}

Standard foliage sampling in forest monitoring programs is from the top third of the crown (Rautio et al., 2016). We determined a species-specific height correction factor $\left(\mathrm{cf}_{\text {height }}\right)$, allowing us to scale up the treetop foliar $\mathrm{Hg}$ uptake flux to whole-tree foliage. The species-specific height correction factor equals the multiplication of two ratios: (i) the ratio $r_{\text {conc.coeff. of the linear regression coefficient }}$ ( $\mathrm{n} \mathrm{Hg} \mathrm{g} \mathrm{g}_{\text {d.w. }}^{-1}$ month $^{-1}$ ) of $\mathrm{Hg}$ concentrations in foliar samples over the growing season at ground/mid canopy level to the equivalent coefficient at top canopy level and (ii) the ratio $r_{\text {LMA }}$ of average LMA at ground/mid canopy level to the average LMA at top canopy level (Eq. 5).

$$
\begin{aligned}
\mathrm{cf}_{\text {height }} & =r_{\text {conc.coeff. }} \times r_{\text {LMA }} \\
& =\frac{\text { conc.coeff.ground }}{\text { conc.coeff.top canopy }} \times \frac{\text { LMA }_{\text {ground }}}{\text { LMA }_{\text {top canopy }}}
\end{aligned}
$$

According to ecosystem models on light attenuation and photosynthesis in tree canopies (Hirose, 2004; Körner, 2013; Monsi and Saeki, 2004), the three top canopy layers of leaf area intercept almost $90 \%$ of available sunlight, leaving the lower leaf layers with reduced light. We thus assume that the top three canopy layers of leaf area index (LAI; $\mathrm{m}_{\text {leaf }}^{2} \mathrm{~m}_{\text {ground }}^{-2}$ ) mainly consist of sun-adapted foliage (i.e., sun leaves) with $\mathrm{Hg}$ uptake rates corresponding to the uptake rates measured at top canopy. Leaf area indices and vertical foliar biomass distribution differ among tree species (Fichtner et al., 2013; Hakkila, 1991; Sharma et al., 2016; Tahvanainen and Forss, 2008; Temesgen et al., 2005). We did not apply a height correction for tree species with a $\mathrm{LAI} \leq 3$. For tree species with leaf area indices $>3$, we assumed the following speciesspecific foliar $\mathrm{Hg}$ uptake flux of the whole tree foliage (uptake $F$ ) in extension to Eq. (1):

uptake $F_{\text {ground area }}=$ uptake $R_{\text {top canopy; leaf area }}$

$$
\times\left(3+\mathrm{cf}_{\text {height }} \times(\mathrm{LAI}-3)\right) .
$$

Final values of $\mathrm{cf}_{\text {height }}$ are summarized in Sect. S11 and Table S5. 


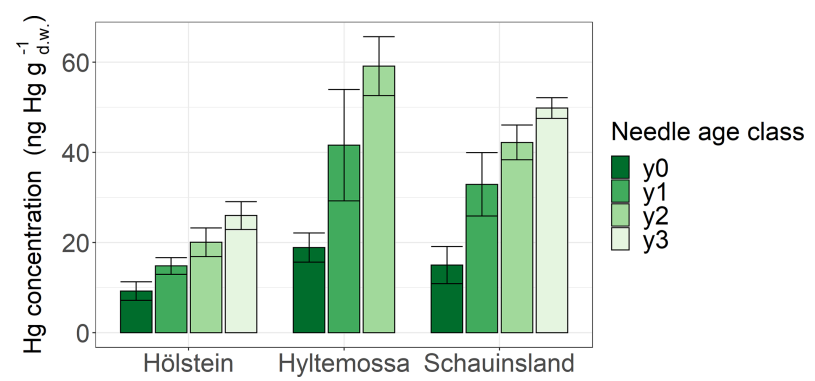

Figure 3. $\mathrm{Hg}$ concentrations $\left(\mathrm{ng} \mathrm{g}_{\mathrm{d} . \mathrm{w}}^{-1}\right.$ ) in spruce needles of four different age classes sampled at three research sites (Hölstein, Hyltemossa and Schauinsland) at the end of the 2018 growing season (October-November). Age class $y_{0}$ represents current-season needles, and age classes $y_{1}, y_{2}$ and $y_{3}$ represent 1-, 2- and 3-year-old needles, respectively. Error bars denote 1 standard deviation of samples taken from multiple trees at each site.

\section{Results and discussion}

\subsection{Effect of needle age on foliar $\mathrm{Hg}$ uptake}

Spruce and pine revealed increasing $\mathrm{Hg}$ concentration with needle age at all sites (Fig. S3). In order to demonstrate the increase in $\mathrm{Hg}$ concentration with needle age class, we display results from Hölstein, Hyltemossa and Schauinsland (Fig. 3). The average late-season $\mathrm{Hg}$ concentration in 1year-old $\left(y_{1}\right)$ spruce needles was by a factor of $1.8 \pm 0.4$ (mean \pm SD of all sites) times higher than the average lateseason $\mathrm{Hg}$ concentration in current-season $\left(y_{0}\right)$ spruce needles. From spruce needle age classes $y_{2}$ to $y_{1}$, the ratio of average $\mathrm{Hg}$ concentrations was $1.3 \pm 0.1$, and from $y_{3}$ to $y_{2}$ it was $1.4 \pm 0.1$. For pine the corresponding ratio was $1.9 \pm 0.2$ (mean $\pm \mathrm{SD}$ of all sites) from $y_{1}$ to $y_{0}$ needles. Consequently, needle $\mathrm{Hg}$ concentrations in spruce and pine almost doubled from the season of sprouting to the subsequent growing season 1 year later. Needles older than 1 year $\left(y_{2}, y_{3}\right)$ continue to accumulate $\mathrm{Hg}$ albeit at a slower rate than younger needles $\left(y_{0}, y_{1}\right)$. This finding is in agreement with previous studies that reported positive trends of $\mathrm{Hg}$ concentration in spruce needles from age classes $y_{1}$ to $y_{4}$ (Hutnik et al., 2014; Navrátil et al., 2019; Ollerova et al., 2010).

We systematically investigated age dependency of $\mathrm{Hg}$ accumulation rates using 292 spruce and 24 pine needle samples of age classes $y_{0}$ to $y_{6}$ sampled by the Bavarian State Institute of Forestry in 2015 and 2017 (Sect. 2.5). The relative accumulation rate (RAR) represents the $\mathrm{Hg}$ accumulation of an individual needle age class normalized to the respective $\mathrm{Hg}$ accumulation rate in the current-season $y_{0}$ needles (Eq. 2). Needles of all age classes continue to accumulate $\mathrm{Hg}$, which is in concurrence with our $2018 \mathrm{Hg}$ concentrations of needles $y_{0}$ to $y_{3}$ (Fig. 3). However, RARs decrease with needle age (Fig. 4). Assuming a linear decline in $\mathrm{Hg}$ uptake with spruce needle age, the mature needles $\left(y_{n}\right)$ took up $-0.17 \pm 0.03$ (linear regression coefficient $\pm \mathrm{SE}$ ) in

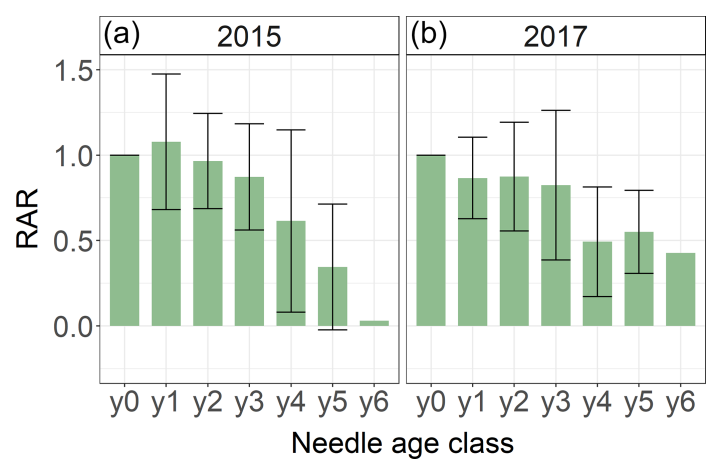

Figure 4. Average relative $\mathrm{Hg}$ accumulation rates (RAR) of 292 spruce needle samples of age classes $y_{0}$ and $y_{6}$ taken by the Bavarian State Institute of Forestry in the two sampling years of 2015 (a) and 2017 (b). The RAR represents the ratio of average $\mathrm{Hg}$ accumulation rate of the respective needle age class to the $\mathrm{Hg}$ accumulation of needle age class $0\left(y_{0}\right)$. Error bars denote 1 standard deviation for RAR of needles sampled from multiple trees and sites.

2015 and $-0.10 \pm 0.02$ (linear regression coefficient \pm SE) in 2017 than the previous age class $y_{n-1}$. The negative linear trend of pine needle $\mathrm{Hg}$ uptake was $-0.18 \pm 0.02$ (linear regression coefficient $\pm \mathrm{SE}$ ) in 2015 samples (from $y_{0}$ to $y_{2}$ $\mathrm{Hg}$ uptake) and -0.17 (linear regression coefficient) in 2017 samples (from $y_{0}$ to $y_{1} \mathrm{Hg}$ uptake).

The decline of Hg RAR with age could be related to a decrease in physiological activity with needle age. The rate of photosynthesis and stomatal conductance decreases in older needles (Freeland, 1952; Jensen et al., 2015; Op de Beeck et al., 2010; Robakowski and Bielinis, 2017; Warren, 2006; Wieser and Tausz, 2007). Consequently, a physiologically less active older needle accumulates less $\mathrm{Hg}(0)$. Additionally, adsorption of $\mathrm{Hg}(0)$ to needle wax layers as a possible nonstomatal uptake pathway might be minimized in older needles, because aging needles suffer from cuticular wax degradation (Burkhardt and Pariyar, 2014; Güney et al., 2016). As older needles exhibited higher $\mathrm{Hg}$ concentrations than younger needles, the $\mathrm{Hg}$ re-emission flux might increase with age. Differences in Hg RARs between sampling years 2015 and 2017 (Fig. 4) could be the result of climatic conditions during the 2 years, like precipitation rates, temperature or vapor pressure deficit, which impact needle stomatal conductance and possibly stomatal $\mathrm{Hg}(0)$ uptake (Blackwell et al., 2014).

The continued $\mathrm{Hg}$ accumulation by needles over their entire life cycle has implications for the comparability of foliar $\mathrm{Hg}$ concentrations in needles and deciduous leaves. Deciduous leaves (beech and oak) exhibit higher average $\mathrm{Hg}$ concentrations than coniferous needles (pine and spruce) of the same age $\left(y_{0}\right)$ (see Table S4 for data from the Hölstein site). However, multiyear-old pine and spruce needles can reach average $\mathrm{Hg}$ concentration values higher than leaves (Sect. S8). We stress that needle age has to be reported in publications in order to avoid confusion when comparing fo- 
liar $\mathrm{Hg}$ concentrations of tree functional groups (deciduous vs. coniferous). Furthermore, $\mathrm{Hg}$ concentrations of all needle age classes have to be taken into account when calculating foliar $\mathrm{Hg}$ pools of coniferous forests (see Sect. S9 for an exemplary needle $\mathrm{Hg}$ pool calculation).

From RAR values of our systematic needle analysis (Fig. 4), we calculated needle age correction factors $\left(\mathrm{cf}_{\text {age }}\right)$ according to Eq. (3) in order to scale up $\mathrm{Hg}$ uptake fluxes determined for $y_{0}$ needles to $\mathrm{Hg}$ uptake fluxes in needles of all age classes (Eq. 4). The correction factor $\mathrm{cf}_{\text {age }}$ was $0.79 \pm 0.03$ (factor according to Eq. $3 \pm \mathrm{SE}$ ) for spruce and $0.87 \pm 0.06$ (factor according to Eq. $3 \pm \mathrm{SE}$ ) for pine (see Sect. S6 for details).

\subsection{Effect of crown height on foliar $\mathrm{Hg}$ content}

Foliar $\mathrm{Hg}$ concentration, leaf mass per area (LMA) and $\mathrm{Hg}$ content normalized to leaf area measured at Hölstein exhibited vertical variation with crown height (Fig. 5). In the following, we discuss all data relative to values measured at top canopy. Top canopy represents the foliage sampling height at the sun-exposed treetop, mid canopy describes the middle height range of sampled trees and ground level represents chest height $(1.5 \mathrm{~m})$.

$\mathrm{Hg}$ concentrations of beech (Fig. 5a), oak and spruce were lower in top canopy foliage than in foliage growing at ground level. By the end of the growing season (October), average $\mathrm{Hg}$ concentration in top canopy (33-38 $\mathrm{m}$ ) beech leaves was 0.84 times and 0.72 times the average $\mathrm{Hg}$ concentration at mid canopy (18-21 m) and ground level $(1.5 \mathrm{~m})$, respectively. For oak, the ratio of average $\mathrm{Hg}$ concentrations in top canopy (28-38 m) leaves to mid canopy (19-22 m) leaves was 0.92, and for current-season spruce needles the respective ratio was 0.85 from top canopy $(43-47 \mathrm{~m}$ ) to mid canopy (25$34 \mathrm{~m}$ ) needles (spruce needles sampled in September 2019; see Sect. 2.2).

LMA of foliage samples from top canopies was higher than LMA of foliage samples from lower tree heights (Fig. 5b exemplary for beech). The season-averaged LMA ratio of top canopy foliar samples to ground foliar samples was 2.9 for beech, 1.3 for oak and 1.6 for spruce.

Because of the large vertical LMA gradient, foliar $\mathrm{Hg}$ content normalized to leaf area exhibited an opposite vertical gradient with tree height compared to $\mathrm{Hg}$ concentrations (Fig. 5c exemplary for beech). By the end of the growing season $\mathrm{Hg}$ content normalized to leaf area in top canopy (33$38 \mathrm{~m}$ ) beech leaves was 1.17 times the $\mathrm{Hg}$ content per area in mid canopy (18-21 m) and 1.91 times in ground-level $(1.5 \mathrm{~m})$ leaves. The equivalent ratio of $\mathrm{Hg}$ content per area in oak leaves was 1.13 from top canopy (28-38 m) to mid canopy (19-22 m) and 1.55 for spruce needles from top (43-47 m) to mid canopy (25-34 m).

Gradients of LMA with tree height are a result of leaf adaptation to changing light conditions and have previously been reported by multiple studies (Konôpka et al., 2016;
Marshall and Monserud, 2003; Merilo et al., 2009; Morecroft and Roberts, 1999; Stancioiu and O'Hara, 2006; Xiao et al., 2006). Leaves exposed to intense sunlight in tree canopies tend to grow thicker and denser and thereby accumulate more photosynthesizing biomass per unit surface area (Niinemets et al., 2001; Sonnewald, 2013). It is thus likely that foliar $\mathrm{Hg}$ content per gram dry weight is diluted in sun-exposed canopy leaves relative to lower-growing shade leaves explaining the observed gradient in foliar $\mathrm{Hg}$ concentrations with tree height (Fig. 5a). Foliar $\mathrm{Hg}$ content normalized to leaf area (ng Hg m $\mathrm{m}_{\text {leaf }}^{-2}$; Fig. $5 \mathrm{c}$ ) is derived from the multiplication of $\mathrm{Hg}$ concentrations and respective LMA. As the gradient of LMA values with height (Fig. 5b) is reversed to and steeper than the gradient in $\mathrm{Hg}$ concentrations with height (Fig. 5a), foliar Hg content per leaf area (Fig. 5c) decreases from top to ground level. Therefore, care has to be taken when comparing different data sets of foliar $\mathrm{Hg}$ concentrations, as foliar $\mathrm{Hg}$ concentrations depend on leaf morphology, which varies with height and tree species.

\subsection{Effect of crown height on foliar $\mathrm{Hg}$ uptake rates per leaf area}

$\mathrm{Hg}$ uptake rates per leaf area (uptake $R_{\text {leaf area }}$ ) were higher in top canopy compared to mid canopy/ground level by a ratio of 2.19 for beech, 1.22 for oak and 1.72 for spruce. Thus, foliage takes up more $\mathrm{Hg}$ per leaf area at top canopy level than at ground level (Fig. 6a exemplary for beech). We propose two mechanisms that possibly explain increasing $\mathrm{Hg}$ uptake rates per leaf area with crown height. The first mechanism is vertical variation in stomatal density and stomatal conductance: leaves from the top of the canopy (sun leaves) have been reported to exhibit a significantly higher mean stomatal density than leaves within the canopy (shade leaves) (Poole et al., 1996). A higher stomatal density (number of stomata pores per unit leaf area) is associated with a higher $\mathrm{Hg}$ content per leaf area (Laacouri et al., 2013). The observed gradient of higher Hg uptake per leaf area towards the top canopy (Fig. 6a) possibly reflects higher stomatal density in sun leaves compared to shade leaves at ground level. Supplementary to stomatal density, we hypothesize that stomatal conductance to water vapor is a defining parameter for foliar $\mathrm{Hg}$ uptake per area. We measured stomatal conductance under dry conditions at Hölstein at noon on 17 July 2019 and observed higher average values in top canopy beech leaves than in ground-level beech leaves (Fig. 6b). Stomatal conductance to water vapor is subject to temporal change depending on meteorological conditions and soil moisture content (Körner, 2013; Schulze, 1986). Nevertheless, the observed gradient in stomatal conductance with tree height (Fig. 6b) conceivably indicates that foliar-atmosphere exchange of water vapor and $\operatorname{Hg}(0)$ are related. The second mechanism is vertical air $\mathrm{Hg}(0)$ gradient: we observed a small gradient in atmospheric $\mathrm{Hg}(0)$ from $1.6 \mathrm{ng} \mathrm{m}^{-3}$ at the top (35 ma.g.1.) to $1.4 \pm 0.08 \mathrm{ng} \mathrm{m}^{-3}$ at 

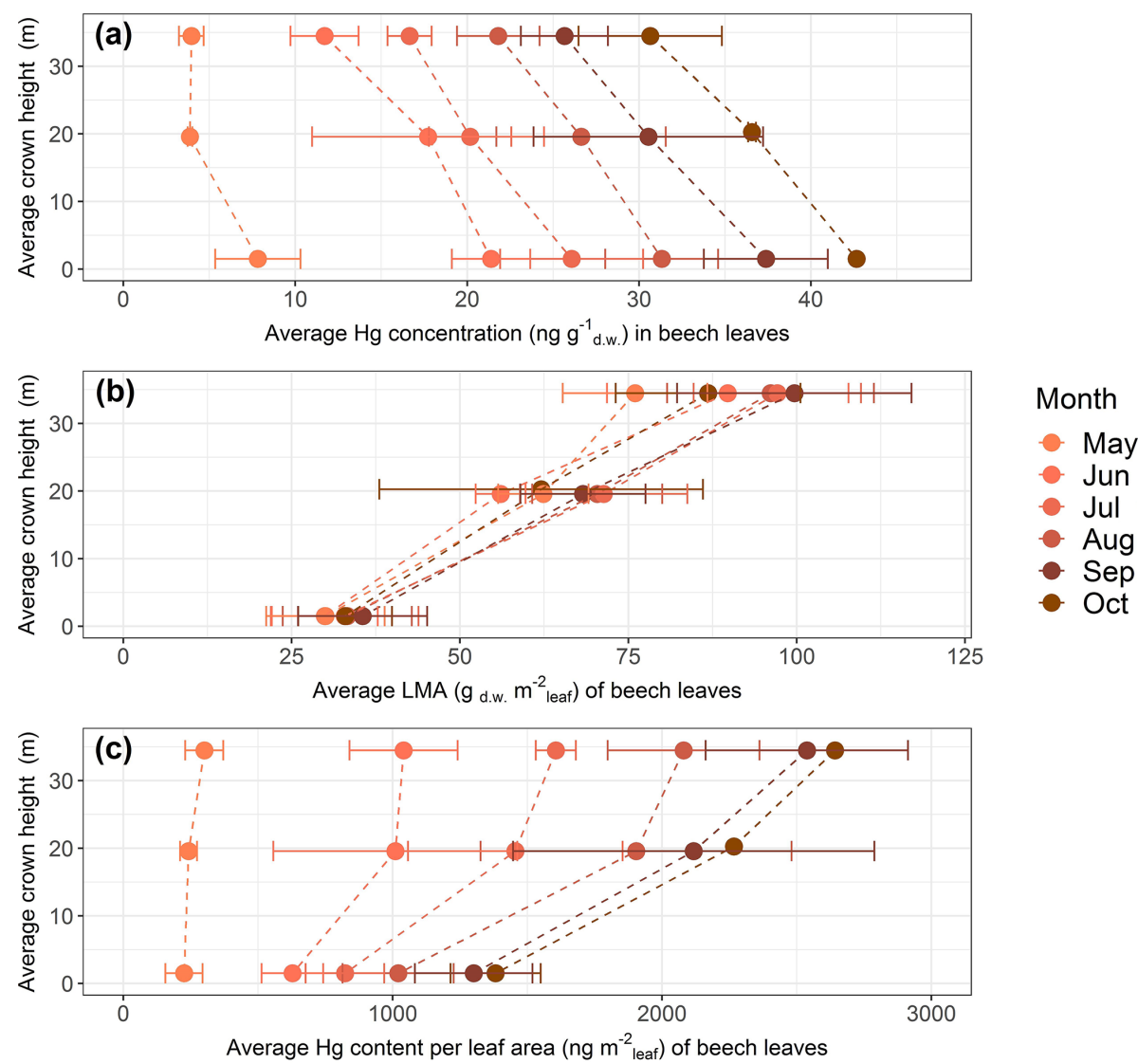

Figure 5. Average values of beech leaf parameters as a function of average tree crown height in meters above ground level at Hölstein, Switzerland, over the course of the 2018 growing season: (a) $\mathrm{Hg}$ concentrations ( $\mathrm{ng} \mathrm{Hg} \mathrm{g}_{\mathrm{d} . w .}$ ), (b) leaf mass per area (LMA; $\mathrm{g}_{\mathrm{d} . w .} \mathrm{m}_{\text {leaf }}^{-2}$ ) and (c) $\mathrm{Hg}$ content normalized to projected leaf area ( $\mathrm{ng} \mathrm{Hg} \mathrm{m}_{\text {leaf }}^{-2}$ ). Error bars denote 1 standard deviation of leaf samples from multiple beech trees $(n=3-5)$.

ground level (1.6 ma.g.l.) integrated over the growing season 2018 (May-October) and from $1.7 \mathrm{ng} \mathrm{m}^{-3}$ (35 ma.g.l.) to $1.4 \mathrm{ng} \mathrm{m}^{-3}$ (1.6 ma.g.1.) integrated over the growing season 2019 (May-September) (Fig. 6c). We hypothesize that depletion in atmospheric $\mathrm{Hg}(0)$ within the canopy was driven by foliar uptake of atmospheric $\mathrm{Hg}(0)$ (Fu et al., 2016; Jiskra et al., 2019). The vertical $\mathrm{Hg}(0)$ gradient in air possibly contributed to the gradient of $\mathrm{Hg}$ content per leaf area in beech, oak and spruce from top canopy to ground/mid canopy, because ground-level leaf area intercepts less air $\mathrm{Hg}(0)$ than canopy leaf area. A caveat to consider is that the $\mathrm{Hg}(0)$ concentration gradient measured depends on sampling rates of deployed passive samplers, which were considered to be constant with height (detailed discussion in Sect. S7).

Re-emission of $\mathrm{Hg}(0)$ from foliage driven by photoreduction of $\mathrm{Hg}(\mathrm{II})$ to $\mathrm{Hg}(0)$ can counterbalance gross uptake of $\mathrm{Hg}(0)$ (Yuan et al., 2019). Re-emission rates will be enhanced in the top of the canopy due to higher light availability. However, re-emission rates were not large enough to compensate for higher $\mathrm{Hg}$ uptake per leaf area by top canopy leaves compared to ground-level leaves (Fig. 6a).

\subsection{Effect of tree functional group (deciduous vs. coniferous) on foliar $\mathrm{Hg}$ uptake}

Broad leaves of deciduous species (beech and oak) in Hölstein exhibited on average approximately 5 times higher $\mathrm{Hg}$ concentration increases $\left(5.3 \pm 0.6 \mathrm{ng} \mathrm{Hg} \mathrm{g}_{\text {d.w. }}^{-1}\right.$ month $^{-1}$; mean $\pm \mathrm{SE}$ ) compared to current-season pine and spruce needles $\left(1.1 \pm 0.4 \mathrm{ng} \mathrm{Hg} \mathrm{g}_{\text {d.w. }}^{-1}\right.$ month $^{-1}$; mean $\pm \mathrm{SE}$ ) (Fig. 7a). Higher $\mathrm{Hg}$ concentrations in broad leaves directly compared to conifer needles were also found by Blackwell and Driscoll (2015) and Navrátil et al. (2016) but not by Hall and St. Louis (2004) or Obrist et al. (2011, 2012). Foliar $\mathrm{Hg}$ uptake rates normalized to leaf area in Hölstein were approximately 3 times higher in broad leaves $\left(622 \pm 84 \mathrm{ng} \mathrm{Hg} \mathrm{m}_{\text {leaf }}^{-2}\right.$ month $^{-1}$; mean $\left.\pm \mathrm{SE}\right)$ than in conifer needles ( $222 \pm 81 \mathrm{ng} \mathrm{Hg} \mathrm{m}_{\text {leaf }}^{-2}$ month $^{-1}$; mean $\pm \mathrm{SE}$ ) (Fig. 7b). Thus, our results exhibit higher foliar $\mathrm{Hg}$ uptake per leaf area in broad leaves than in current-season conifer needles.

We propose that $\mathrm{Hg}$ uptake rates have to be assessed in the context of different physiological characteristics of 

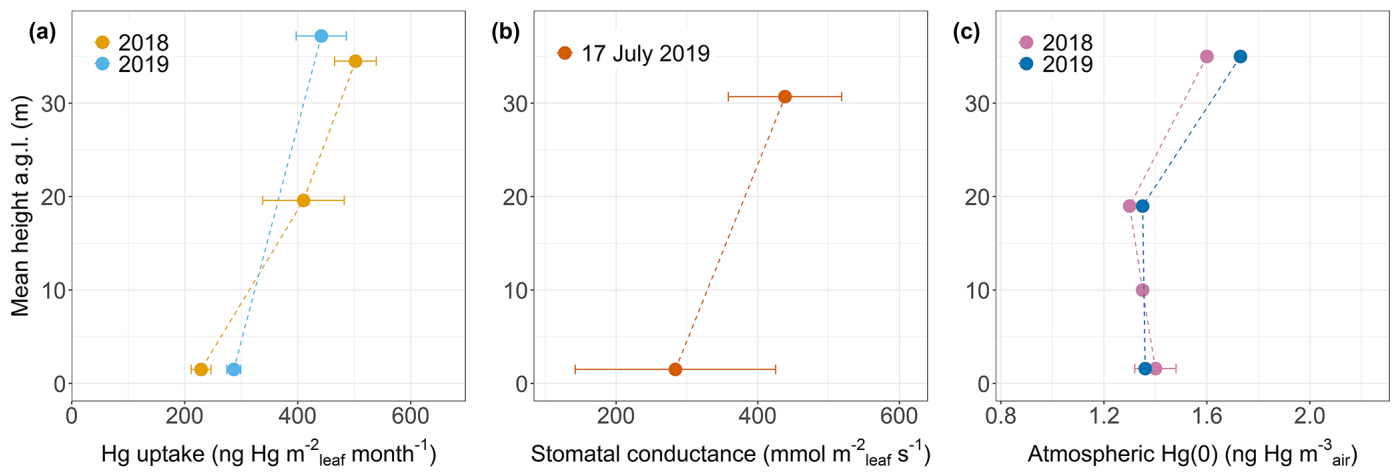

Figure 6. (a) Foliar $\mathrm{Hg}$ uptake rate per leaf area $\left(\mathrm{ng} \mathrm{Hg} \mathrm{m}_{\text {leaf }}^{-2}\right.$ month $^{-1}$; linear regression coefficient $\pm \mathrm{SE}$ ) by beech leaves at various tree heights (m) at Hölstein during two growing seasons of 2018 and 2019. (b) Stomatal conductance to water vapor (mmol $\mathrm{m}_{\text {leaf }}^{-2} \mathrm{~s}^{-1}$; mean \pm SD) measured in Hölstein beech leaves at top canopy and ground level under dry conditions at noon on 17 July 2019. (c) Atmospheric $\mathrm{Hg}(0)\left(\mathrm{ng} \mathrm{Hg} \mathrm{m}_{\text {air }}^{-3}\right)$ at various heights in Hölstein measured with passive air samplers and integrated over the 2018 and 2019 growing season. Error bars at ground-level height $(1.6 \mathrm{~m})$ of 2018 data denote 1 standard deviation for four passive samplers.
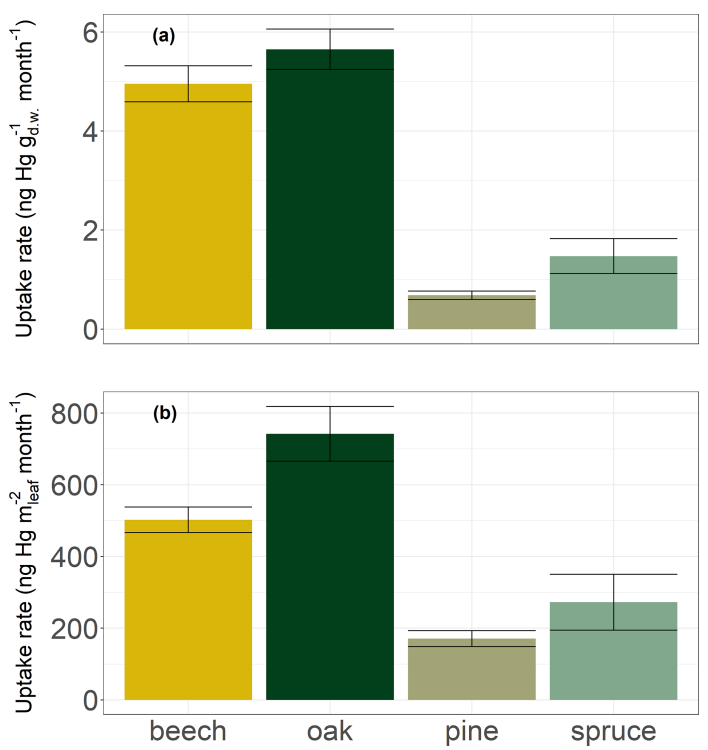

Figure 7. $\mathrm{Hg}$ uptake rates by leaves and current-season needles of four tree species at Hölstein normalized to (a) dry weight in ng Hg g ${ }_{\text {d.w. }}^{-1}$ month $^{-1}$ and (b) leaf area in ng $\mathrm{Hg} \mathrm{m}_{\text {leaf }}^{-2}$ month $^{-1}$. Error bars denote standard errors of the linear regression of foliar $\mathrm{Hg}$ concentrations over the growing season.

conifer needles and broad leaves. Needles generally have a larger LMA ( $245 \pm 62 \mathrm{~g} \mathrm{~m}_{\text {leaf }}^{-2}$ in Hölstein) than broad leaves $\left(79 \pm 38 \mathrm{~g} \mathrm{~m}_{\text {leaf }}^{-2}\right.$ in Hölstein). Plant tissues with large LMA such as needles are associated with low metabolic activity, including photosynthesis and respiration (Körner, 2013; Reich et al., 1997; Wright et al., 2004). Accordingly, the stomatal conductance to water vapor of canopy foliage in Hölstein on 17 July 2019 was lower for coniferous pine needles $\left(289 \pm 137 \mathrm{mmol} \mathrm{m}_{\text {leaf }}^{-2} \mathrm{~s}^{-1}\right.$; mean $\left.\pm \mathrm{SD} ; n=14\right)$ than for broad leaves of beech $\left(438 \pm 80 \mathrm{mmol} \mathrm{m}_{\text {leaf }}^{-2} \mathrm{~s}^{-1}\right.$; mean $\pm \mathrm{SD} ; n=14)$ and oak $\left(849 \pm 221 \mathrm{mmol} \mathrm{m}_{\text {leaf }}^{-2} \mathrm{~s}^{-1}\right.$; mean $\pm \mathrm{SD} ; n=15)$. The variation between foliage functional groups (conifer needles vs. broad leaves) indicates that foliar $\mathrm{Hg}$ uptake is related to stomatal conductance.

\subsection{Foliar Hg uptake fluxes per ground area}

We calculated foliar $\mathrm{Hg}$ uptake fluxes per ground area $\left(\mathrm{m}_{\text {ground }}^{-2}\right)$ by multiplying foliar $\mathrm{Hg}$ uptake rates per leaf area $\left(\mathrm{m}_{\text {leaf }}^{-2}\right)$ with species-specific LAI (Eq. 1). LAI values (mean $\pm \mathrm{SD}$ ) differed among tree species and were highest in spruce $(7.3 \pm 2.1)$ and beech $(7.0 \pm 1.6)$ and lowest in pine (2.9 \pm 1.4$)$ and birch $(2.6 \pm 1.2)$ (Table S2). In general, forests consisting of spruce trees with high LAI might therefore exhibit higher $\mathrm{Hg}$ uptake fluxes than deciduous forests with low average LAI even though $\mathrm{Hg}$ uptake rates per leaf area might be lower for conifer needles than for broad leaves (Sect. 3.4). We applied correction factors for needle age for conifer samples (Eq. 4) and crown height for sites where we collected top canopy samples (Hölstein, Hyltemossa, Norunda and Svartberget) (Eq. 6). The foliar $\mathrm{Hg}$ uptake flux showed a large variation ranging from $2 \mu \mathrm{g} \mathrm{Hg} \mathrm{m}^{-2}$ (Pallas, pine) to $26 \mu \mathrm{g} \mathrm{Hg} \mathrm{m}^{-2}$ (Schauinsland, beech) over the 2018 growing season (Fig. S6). The four sites where samples were collected from top canopy exhibited a smaller range for spruce among sites from 7 to $15 \mu \mathrm{g} \mathrm{Hg} \mathrm{m}^{-2}$ season $^{-1}$ (Fig. 8). Given the systematic variation of $\mathrm{Hg}$ uptake rates with tree height (Fig. 5), we cannot exclude that the inconsistent sampling strategy might have influenced the observed $\mathrm{Hg}$ uptake fluxes among the 10 sampling sites. We will therefore not discuss further the observed variation among sites. To scale up site-based $\mathrm{Hg}$ uptake fluxes, we only consider sites where we consistently sampled the top third of the canopy (Hölstein, Hyltemossa, Norunda and Svartberget). The average foliar $\mathrm{Hg}$ uptake fluxes of each species at the four crown sampling sites (mean \pm SE of sites) 


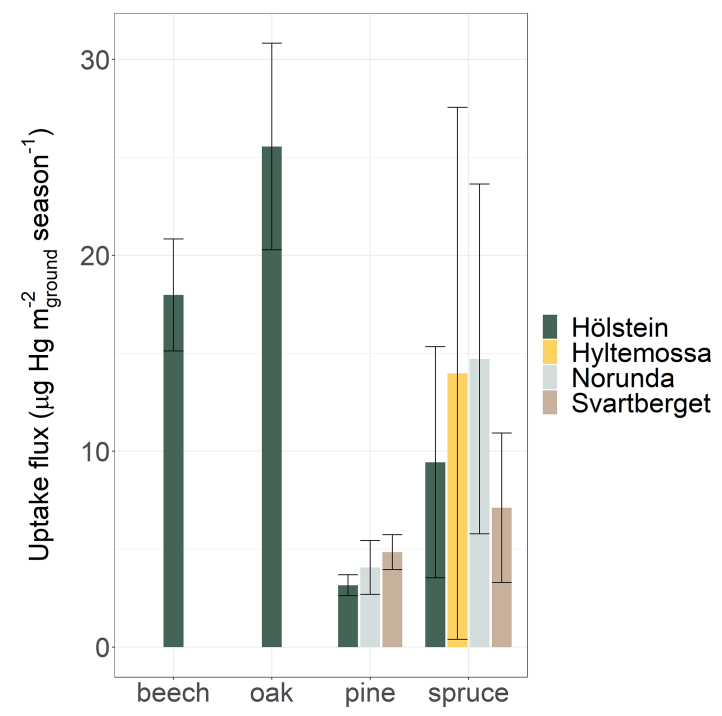

Figure 8. Foliar $\mathrm{Hg}$ uptake fluxes $\left(\mu \mathrm{g} \mathrm{Hg} \mathrm{m}^{-2}\right.$ during the 2018 growing season) at four forested research sites where foliage samples were taken from crown height. Error bars indicate 1 standard error of the regression slope.

during the 2018 growing season were $18 \pm 3 \mu \mathrm{g} \mathrm{Hg} \mathrm{m}{ }^{-2}$ for beech, $26 \pm 5 \mu \mathrm{g} \mathrm{Hg} \mathrm{m}^{-2}$ for oak, $4 \pm 1 \mu \mathrm{g} \mathrm{Hg} \mathrm{m}^{-2}$ for pine and $11 \pm 1 \mu \mathrm{g} \mathrm{Hg} \mathrm{m}^{-2}$ for spruce (see Sect. S15 for standard errors of fluxes). Deciduous trees exhibited higher foliar uptake fluxes compared to coniferous trees resulting from generally higher uptake rates per leaf area (Fig. 7b), owing to higher physiological activity of deciduous trees.

\subsection{Foliar Hg uptake fluxes along a latitudinal gradient in Europe}

We calculated total $\mathrm{Hg}$ uptake fluxes at each research site as the sum of $\mathrm{Hg}$ uptake fluxes of each tree species and research site weighted by the relative abundance of the respective tree species to the other examined tree species at each site (Fig. 9; Table S6). The average foliar $\mathrm{Hg}$ uptake flux of the four research sites where foliage samples were obtained from tree crown heights over the 2018 growing season was $11 \pm 3 \mu \mathrm{g} \mathrm{Hg} \mathrm{m}^{-2}$ (mean $\pm \mathrm{SD}$ ). Spruce needle $\mathrm{Hg}$ uptake fluxes did not exhibit a clear trend with latitude (Fig. 9b with sites sorted for latitude).

The aboveground foliar $\mathrm{Hg}$ uptake fluxes per site (range 6-14 $\mu \mathrm{g} \mathrm{Hg} \mathrm{m}^{-2}$ per growing season) are in the lower range of published $\mathrm{Hg}$ litterfall fluxes in Europe and North America measured for various years, which range from 9.7 to $28.5 \mu \mathrm{g} \mathrm{Hg} \mathrm{m}^{-2} \mathrm{yr}^{-1}$ (Demers et al., 2007; Juillerat et al., 2012; Navrátil et al., 2016; Rea et al., 1996, 2002; Risch et al., 2012, 2017).

The average wet $\mathrm{Hg}$ (II) deposition fluxes measured at Schauinsland, Schmücke, Råö, Bredkälen and Pallas over the course of the sampling period was $2.3 \pm 0.3 \mu \mathrm{g} \mathrm{Hg} \mathrm{m}{ }^{-2}$ (mean $\pm \mathrm{SD}$ ). Wet $\mathrm{Hg}$ (II) deposition fluxes were consistently
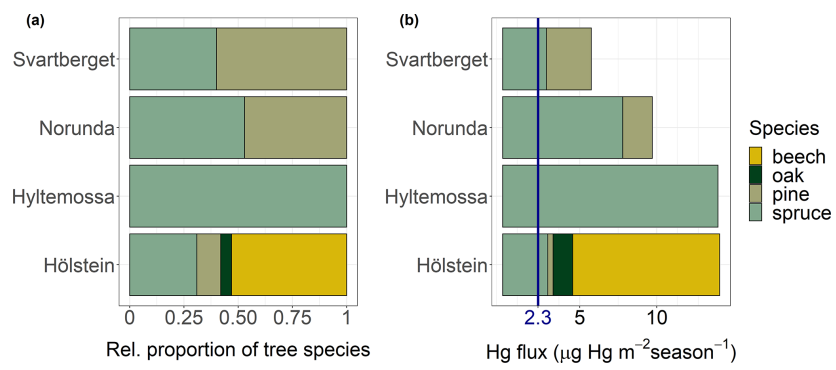

Figure 9. (a) Relative proportion of tree species to each other and (b) foliar $\mathrm{Hg}$ fluxes $\left(\mu \mathrm{g} \mathrm{Hg} \mathrm{m}^{-2}\right.$ over the 2018 growing season) at four European research sites ordered by latitude from south $\left(\right.$ Hölstein at $47^{\circ} \mathrm{N}$ ) to north (Svartberget at $64^{\circ} \mathrm{N}$ ); blue label of $2.3 \mu \mathrm{g} \mathrm{Hg} \mathrm{m}^{-2}$ season $^{-1}$ corresponds to the average wet deposition flux measured at five sites over the course of the sampling period.

lower than foliar Hg uptake fluxes. Our data constrain that foliar $\mathrm{Hg}$ uptake is a major deposition pathway to terrestrial surfaces in Europe, exceeding direct wet deposition of $\mathrm{Hg}$ (II) by a factor of 4 . Note that this assessment only compares $\mathrm{Hg}(0)$ uptake by foliage and does not take into account $\mathrm{Hg}$ incorporated into wood biomass (Navrátil et al., 2019) or $\mathrm{Hg}(0)$ adsorbed to leaf surfaces that is washed off between sampling events as throughfall (Demers et al., 2007; Rea et al., 1996, 2001). Total $\mathrm{Hg}(0)$ deposition fluxes to terrestrial ecosystems, which also include $\mathrm{Hg}(0)$ deposition to soils and litter (Obrist et al., 2014, 2017; Pokharel and Obrist, 2011; Zhang et al., 2009), are therefore expected to be higher than foliar uptake fluxes quantified here.

Averaging species-specific foliar $\mathrm{Hg}$ uptake fluxes and weighting them with the tree species proportion in Europe derived from Brus et al. (2012) yields an average foliar $\mathrm{Hg}$ uptake flux for Europe of $10.4 \pm 2 \mu \mathrm{g} \mathrm{Hg} \mathrm{m}^{-2}$ over the 2018 growing season (weighted mean $\pm \mathrm{SE}$ ). Extrapolation of this weighted mean to the land area of European forests $\left(192.672 \times 10^{6}\right.$ ha) results in a foliar flux of $20 \pm 3 \mathrm{Mg} \mathrm{Hg}$ during the 2018 growing season (see Sect. S14 for details on flux extrapolation and Sect. S15 for error propagation). Under the assumption that tree species in the global temperate zone are distributed equally to tree species in Europe, we estimated an approximate foliar flux of $108 \pm 18 \mathrm{Mg} \mathrm{Hg}$ to the area of global temperate forests $\left(1.04 \times 10^{9} \mathrm{ha}\right.$ ) (Tyrrell et al., 2012) during the 2018 growing season. This global extrapolation is at the lower end of global $\mathrm{Hg}$ litterfall deposition flux ( $163 \mathrm{Mg} \mathrm{Hg} \mathrm{yr}^{-1}$ ) estimated for temperate forests based on a $\mathrm{Hg}$ litterfall flux database of measurements between 1995-2015 (Wang et al., 2016). In order to obtain a more precise foliar $\mathrm{Hg}$ uptake flux estimate to European and global forests, improved spatially resolved foliar $\mathrm{Hg}$ data and comprehensive ground-based forest statistics of tree species composition are needed. 


\section{Conclusions}

We observed that $\mathrm{Hg}$ concentrations in foliage increased over the growing season in broadleaf and coniferous trees. Concentrations of $\mathrm{Hg}$ in multiyear needles increased with age. The foliar $\mathrm{Hg}$ uptake normalized to leaf area was higher on top of the canopy than at ground level. The temporal and vertical variation of foliar $\mathrm{Hg}$ uptake fluxes are consistent with the notion that stomatal uptake represents the main deposition pathway to atmospheric $\mathrm{Hg}(0)$. We emphasize that standardized sampling strategies and reporting of sampling height and needle age class is essential to allow for comparison of foliar $\mathrm{Hg}$ results among different studies.

We developed a bottom-up approach to quantify foliar $\mathrm{Hg}(0)$ uptake fluxes on an ecosystem scale, considering the systematic variations in crown height, needle age and tree species. Our bottom-up approach integrates aboveground foliar $\mathrm{Hg}(0)$ uptake rates over the entire growing season and the whole tree level. We thus suggest that our approach provides a robust method to assess foliar $\mathrm{Hg}(0)$ uptake fluxes on a species level as well as on an ecosystem scale at a high temporal resolution. This approach is complementary to litterfall mass balance approaches, which provide $\mathrm{Hg}$ deposition estimates integrated over an entire year. We suspect that the foliar $\mathrm{Hg}$ uptake fluxes measured in this study represent net $\mathrm{Hg}(0)$ uptake fluxes as the increase of foliar $\mathrm{Hg}$ concentration was linear with time, which would include possible $\mathrm{Hg}(0)$ re-emission from foliage (Yuan et al., 2019). With the bottom-up approach presented here, it is thus possible to obtain net foliar $\operatorname{Hg}(0)$ uptake fluxes that are temporally resolved over the growing season, depending on the number of temporal foliar $\mathrm{Hg}$ measurements. The linear uptake of $\mathrm{Hg}(0)$ observed in this study across 10 European sites and for six different species suggests that forest foliage takes up $\mathrm{Hg}(0)$ from the atmosphere over the entire growing season, supporting the notion that foliar uptake of $\mathrm{Hg}(0)$ drives the seasonal depletion in atmospheric $\mathrm{Hg}(0)$ in the Northern Hemisphere (Jiskra et al., 2018).

Our study demonstrates that foliar Hg uptake is an important deposition pathway to terrestrial surfaces and exceeds wet deposition by a factor of 4 on average. In contrast to $\mathrm{Hg}(\mathrm{II})$ in wet deposition, which is monitored in atmospheric deposition networks (EMEP, 2016; Pacyna et al., 2009), there is no standardized and established program to monitor $\mathrm{Hg}$ deposition in foliage or litterfall across Europe. We call for including foliar mercury deposition in monitoring networks on a country and international level. Robust and standardized data on the development of $\mathrm{Hg}$ deposition to foliage and forest ecosystems will allow researchers to assess the effectiveness of the Minamata convention on mercury (Minamata Convention, 2019) and impact of climate change on mercury deposition to terrestrial ecosystems in the future.
Data availability. Foliar $\mathrm{Hg}$ uptake fluxes at all sites are given in the Supplement. $\mathrm{Hg}$ concentrations and metadata of all foliage samples collected in this study are available at: https://doi.org/10.5281/zenodo.3957873 (Wohlgemuth, 2020).

Supplement. The supplement related to this article is available online at: https://doi.org/10.5194/bg-17-6441-2020-supplement.

Author contributions. MJ designed the study. LW and CJ carried out the field sampling and analytical measurements. LW performed the data analysis. SO and GH gave experimental advice and sampling support. CA and AK provided feedback and research infrastructure. LW wrote the article in consultation with MJ. All authors discussed the article and provided comments.

Competing interests. The authors declare that they have no conflict of interest.

Acknowledgements. We are grateful to Fabienne Bracher, Emanuel Glauser and Judith Kobler Waldis for their help with foliage sample preparation and analysis. We acknowledge the Swiss Canopy Crane II (SCCII) site at Hölstein operated by the Physiological Plant Ecology Research Group at the University of Basel and thank André Kühne and Matthias Arend for their on-site support. We thank Frank Wania from the University of Toronto for contributing valuable mercury passive air samplers and activated carbon. Hans-Peter Dietrich and Stephan Raspe from the Bavarian State Institute of Forestry thankfully provided us with multiyear foliage samples from Bavaria. We acknowledge ICOS Sweden for providing data from Hyltemossa, Norunda and Svartberget, and we would like to thank Irene Lehner, Tobias Biermann, Michal Heliasz, Antonin Kusbach, Johan Ahlgren, Ulla Nylander, Mikael Holmlund, Pernilla Löfvenius and Per Marklund for assistance in foliage sampling and experimental support. Volkmar Timmermann and Helge Meissner from NIBIO gratefully organized and performed foliage sampling at Hurdal. We thank Elke Bieber, Frank Meinhardt and Rita Junek from the German Environment Agency for their support at Schauinsland and Schmücke air monitoring sites. We are grateful to Michelle Nerentorp Mastromonaco and Ingvar Wängberg from IVL and Eva-Britt Edin for foliage sampling support and site access at Råö and Bredkälen. We thank Katriina Kyllönen from FMI and Valtteri Hyöky for foliage sampling assistance and site access at Pallas. Special thanks go to Jann Launer for drawing Fig. 2. Finally, we thank Christian Körner for his helpful answers to questions on plant physiology.

Financial support. The work of this paper was funded by the Swiss National Science Foundation (SNSF) (project 174101). The crane at the SCCII site is funded by the Swiss Federal Office for the Environment (FOEN). The Swedish research infrastructures, ICOS and SITES, are both financed by the Swedish Research Council and partner universities. 
Review statement. This paper was edited by Minhan Dai and reviewed by Charles T. Driscoll and one anonymous referee.

\section{References}

Ariya, P. A., Amyot, M., Dastoor, A., Deeds, D., Feinberg, A., Kos, G., Poulain, A., Ryjkov, A., Semeniuk, K., Subir, M., and Toyota, K.: Mercury physicochemical and biogeochemical transformation in the atmosphere and at atmospheric interfaces: a review and future directions, Chem. Rev., 115, 3760-3802, https://doi.org/10.1021/cr500667e, 2015.

Assad, M., Parelle, J., Cazaux, D., Gimbert, F., Chalot, M., and Tatin-Froux, F.: Mercury uptake into poplar leaves, Chemosphere, 146, 1-7, https://doi.org/10.1016/j.chemosphere.2015.11.103, 2016.

Bishop, K., Shanley, J. B., Riscassi, A., de Wit, H. A., Eklöf, K., Meng, B., Mitchell, C., Osterwalder, S., Schuster, P. F., Webster, J., and Zhu, W.: Recent advances in understanding and measurement of mercury in the environment: Terrestrial Hg cycling, Sci. Total Environ., 721, 137647, https://doi.org/10.1016/j.scitotenv.2020.137647, 2020.

Blackwell, B. D. and Driscoll, C. T.: Using foliar and forest floor mercury concentrations to assess spatial patterns of mercury deposition, Environ. Pollut., 202, 126-134, https://doi.org/10.1016/j.envpol.2015.02.036, 2015.

Blackwell, B. D., Driscoll, C. T., Maxwell, J. A., and Holsen, T. M.: Changing climate alters inputs and pathways of mercury deposition to forested ecosystems, Biogeochemistry, 119, 215-228, https://doi.org/10.1007/s10533-014-9961-6, 2014.

Brus, D. J., Hengeveld, G. M., Walvoort, D. J. J., Goedhart, P. W., Heidema, A. H., Nabuurs, G. J., and Gunia, K.: Statistical mapping of tree species over Europe, Eur. J. For. Res., 131, 145-157, https://doi.org/10.1007/s10342-011-0513-5, 2012.

Burkhardt, J. and Pariyar, S.: Particulate pollutants are capable to "degrade" epicuticular waxes and to decrease the drought tolerance of Scots pine (Pinus sylvestris L.), Environ. Pollut., 184, 659-667, https://doi.org/10.1016/j.envpol.2013.04.041, 2014.

Bushey, J. T., Nallana, A. G., Montesdeoca, M. R., and Driscoll, C. T.: Mercury dynamics of a northern hardwood canopy, Atmos. Environ., 42, 6905-6914, https://doi.org/10.1016/j.atmosenv.2008.05.043, 2008.

Demers, J. D., Driscoll, C. T., Fahey, T. J., and Yavitt, J. B.: Mercury cycling in litter and soil in different forest types in the Adirondack Region, New York, USA, Ecol. Appl., 17, 13411351, https://doi.org/10.1890/06-1697.1, 2007.

Demers, J. D., Blum, J. D., and Zak, D. R.: Mercury isotopes in a forested ecosystem: Implications for air-surface exchange dynamics and the global mercury cycle, Global Biogeochem. Cy., 27, 222-238, https://doi.org/10.1002/gbc.20021, 2013.

Driscoll, C. T., Mason, R. P., Chan, H. M., Jacob, D. J., and Pirrone, N.: Mercury as a global pollutant: sources, pathways, and effects, Environ. Sci. Technol., 47, 4967-4983, https://doi.org/10.1021/es305071v, 2013.

EMEP: Air pollution trends in the EMEP region between 1990 and 2012, Joint Report, CCC-Report 1/2016, available at: http://nora. nerc.ac.uk/id/eprint/513779/ (last access: 14 December 2020), 2016.
Enrico, M., Roux, G. L., Marusczak, N., Heimbürger, L.-E., Claustres, A., Fu, X., Sun, R., and Sonke, J. E.: Atmospheric mercury transfer to peat bogs dominated by gaseous elemental mercury dry deposition, Environ. Sci. Technol., 50, 2405-2412, https://doi.org/10.1021/acs.est.5b06058, 2016.

Ericksen, J. A. and Gustin, M. S.: Foliar exchange of mercury as a function of soil and air mercury concentrations, Sci. Total Environ., 324, 271-279, https://doi.org/10.1016/j.scitotenv.2003.10.034, 2004.

EU: European Commission, 2011/833/EU: Commission Decision of 12 December 2011 on the reuse of Commission documents, available at: https://eur-lex.europa.eu/eli/dec/2011/833/oj (last access: 14 December 2020), 2011.

Fichtner, A., Sturm, K., Rickert, C., von Oheimb, G., and Härdtle, W.: Crown size-growth relationships of European beech (Fagus sylvatica L.) are driven by the interplay of disturbance intensity and inter-specific competition, Forest Ecol. Manag., 302, 178184, https://doi.org/10.1016/j.foreco.2013.03.027, 2013.

Fleck, J. A., Grigal, D. F., and Nater, E. A.: Mercury uptake by trees: an observational experiment, Water Air Soil Poll., 115, 513-523, https://doi.org/10.1023/A:1005194608598, 1999.

Freeland, R. O.: Effect of age of leaves upon the rate of photosynthesis in some conifers, Plant Physiol., 27, 685-690, https://doi.org/10.1104/pp.27.4.685, 1952.

Frescholtz, T. F., Gustin, M. S., Schorran, D. E., and Fernandez, G. C. J.: Assessing the source of mercury in foliar tissue of quaking aspen, Environ. Toxicol. Chem., 22, 2114-2119, https://doi.org/10.1002/etc.5620220922, 2003.

Fu, X., Zhu, W., Zhang, H., Sommar, J., Yu, B., Yang, X., Wang, X., Lin, C.-J., and Feng, X.: Depletion of atmospheric gaseous elemental mercury by plant uptake at Mt. Changbai, Northeast China, Atmos. Chem. Phys., 16, 12861-12873, https://doi.org/10.5194/acp-16-12861-2016, 2016.

Garonna, I., de Jong, R., de Wit, A. J., Mücher, C. A., Schmid, B., and Schaepman, M. E.: Strong contribution of autumn phenology to changes in satellite-derived growing season length estimates across Europe (1982-2011), Glob. Change Biol., 20, 3457-3470, https://doi.org/10.1111/gcb.12625, 2014.

Gencarelli, C. N., de Simone, F., Hedgecock, I. M., Sprovieri, F., Yang, X., and Pirrone, N.: European and Mediterranean mercury modelling: Local and long-range contributions to the deposition flux, Atmos. Environ., 117, 162-168, https://doi.org/10.1016/j.atmosenv.2015.07.015, 2015.

Graydon, J. A., St. Louis, V. L., Lindberg, S. E., Hintelmann, H., and Krabbenhoft, D. P.: Investigation of mercury exchange between forest canopy vegetation and the atmosphere using a new dynamic chamber, Environ. Sci. Technol., 40, 4680-4688, https://doi.org/10.1021/es0604616, 2006.

Grigal, D. F.: Inputs and outputs of mercury from terrestrial watersheds: a review, Environ. Rev., 10, 1-39, 2002.

Güney, A., Zimmermann, R., Krupp, A., and Haas, K.: Needle characteristics of Lebanon cedar (Cedrus libani A. Rich.): degradation of epicuticular waxes and decrease of photosynthetic rates with increasing needle age, Turk. J. Agric. For., 40, 386-396, https://doi.org/10.3906/tar-1507-63, 2016.

Hakkila, P.: Hakkuupoistuman Latvusmassa: Crown mass of trees at the harvesting phase, The Finnish Forest Research Institute, available at: https://core.ac.uk/download/pdf/52273555.pdf (last access: 14 December 2020), 1991. 
Hall, B. D. and St. Louis, V. L.: Methylmercury and Total Mercury in Plant Litter Decomposing in Upland Forests and Flooded Landscapes, Environ. Sci. Technol., 38, 5010-5021, https://doi.org/10.1021/es049800q, 2004.

Hirose, T.: Development of the Monsi-Saeki Theory on Canopy Structure and Function, Ann. Bot.-London, 95, 483-494, https://doi.org/10.1093/aob/mci047, 2004.

Hutnik, R. J., McClenahen, J. R., Long, R. P., and Davis, D. D.: Mercury Accumulation in Pinus nigra (Austrian Pine), Northeast. Nat., 21, 529-540, https://doi.org/10.1656/045.021.0402, 2014.

Iio, A. and Ito, A.: A Global Database of Field-observed Leaf Area Index in Woody Plant Species, 1932-2011, Data set available online from Oak Ridge National Laboratory Distributed Active Archive Center, Oak Ridge, Tennessee, USA, https://doi.org/10.3334/ORNLDAAC/1231, 2014.

Jaffe, D. A., Lyman, S., Amos, H. M., Gustin, M. S., Huang, J., Selin, N. E., Levin, L., ter Schure, A., Mason, R. P., Talbot, R., Rutter, A., Finley, B., Jaeglé, L., Shah, V., McClure, C., Ambrose, J., Gratz, L., Lindberg, S., Weiss-Penzias, P., Sheu, G.-R., Feddersen, D., Horvat, M., Dastoor, A., Hynes, A. J., Mao, H., Sonke, J. E., Slemr, F., Fisher, J. A., Ebinghaus, R., Zhang, Y., and Edwards, G.: Progress on understanding atmospheric mercury hampered by uncertain measurements, Environ. Sci. Technol., 48, 7204-7206, https://doi.org/10.1021/es5026432, 2014.

Jensen, A. M., Warren, J. M., Hanson, P. J., Childs, J., and Wullschleger, S. D.: Needle age and season influence photosynthetic temperature response and total annual carbon uptake in mature Picea mariana trees, Ann. Bot.-London, 116, 821-832, https://doi.org/10.1093/aob/mcv115, 2015.

Jiskra, M., Wiederhold, J. G., Skyllberg, U., Kronberg, R.-M., Hajdas, I., and Kretzschmar, R.: Mercury deposition and re-emission pathways in boreal forest soils investigated with $\mathrm{Hg}$ isotope signatures, Environ. Sci. Technol., 49, 7188-7196, 2015.

Jiskra, M., Sonke, J. E., Obrist, D., Bieser, J., Ebinghaus, R., Myhre, C. L., Pfaffhuber, K. A., Wängberg, I., Kyllönen, K., Worthy, D., Martin, L. G., Labuschagne, C., Mkololo, T., Ramonet, M., Magand, O., and Dommergue, A.: A vegetation control on seasonal variations in global atmospheric mercury concentrations, Nat. Geosci., 11, 244-250, https://doi.org/10.1038/s41561-0180078-8, 2018.

Jiskra, M., Sonke, J. E., Agnan, Y., Helmig, D., and Obrist, D.: Insights from mercury stable isotopes on terrestrial-atmosphere exchange of $\mathrm{Hg}(0)$ in the Arctic tundra, Biogeosciences, 16, 40514064, https://doi.org/10.5194/bg-16-4051-2019, 2019.

JRC: European Commission, Joint Research Centre (JRC): Forest Type Map 2006, available at: https://forest.jrc.ec.europa. eu/en/past-activities/forest-mapping/\#Downloadforestmaps (last access: 14 December 2020), 2010.

Juillerat, J. I., Ross, D. S., and Bank, M. S.: Mercury in litterfall and upper soil horizons in forested ecosystems in Vermont, USA, Environ. Toxicol. Chem., 31, 1720-1729, https://doi.org/10.1002/etc.1896, 2012.

Kahmen, A., Lustenberger, S., Zemp, E., and Erny, B.: The Swiss Canopy Crane Experiment II and the botanical garden (University Basel), DBG, available at: https://www.dbges.de/de/system/ files/Tagung_Bern/Exkursionen/g_08_final_0.pdf, (last access: 14 December 2020), 2019.
Kempeneers, P., Sedano, F., Seebach, L., Strobl, P., and San-Miguel-Ayanz, J.: Data fusion of different spatial resolution remote sensing images applied to foresttype mapping, IEEE T. Geosci. Remote, 49, 4977-4986, https://doi.org/10.1109/TGRS.2011.2158548, 2011.

Konôpka, B., Pajtík, J., Marušák, R., Bošeła, M., and Lukac, M.: Specific leaf area and leaf area index in developing stands of $\mathrm{Fa}-$ gus sylvatica L. and Picea abies Karst., Forest Ecol. Manag., 364, 52-59, https://doi.org/10.1016/j.foreco.2015.12.005, 2016.

Körner, C.: Plant-Environment Interactions, in: Strasburger's Plant Sciences: Including Prokaryotes and Fungi, edited by: Bresinsky, A., Körner, C., Kadereit, J. W., Neuhaus, G., and Sonnewald, U., Springer, Berlin, Heidelberg, Germany, 1065-1166, 2013.

Laacouri, A., Nater, E. A., and Kolka, R. K.: Distribution and uptake dynamics of mercury in leaves of common deciduous tree species in Minnesota, USA, Environ. Sci. Technol., 47, 10462-10470, https://doi.org/10.1021/es401357z, 2013.

Lange, H.: Carbon exchange measurements at a flux tower in Hurdal, SNS/Efinord Growth and Yield Network Conference, 13-15 June 2017; Drøbak, Hurdal and Son, Norway; Book of Abstracts p. 27, available at: http://nordicforestresearch.org/ wp-content/uploads/2018/03/NIBIO-BOK-39-2017.pdf (last access: 14 December 2020), 2017.

Lindroth, A., Heliasz, M., Klemedtsson, L., Friborg, T., Nilsson, M., Löfvenius, O., Rutgersson, A., and Stiegler, C.: ICOS Sweden - a national infrastructure network for greenhouse gas research, EGU Geophys. Res. Abstr., 17, EGU2015-10307-2, 2015.

Lindroth, A., Holst, J., Heliasz, M., Vestin, P., Lagergren, F., Biermann, T., Cai, Z., and Mölder, M.: Effects of low thinning on carbon dioxide fluxes in a mixed hemiboreal forest, Agr. Forest Meteorol., 262, 59-70, https://doi.org/10.1016/j.agrformet.2018.06.021, 2018.

Lodenius, M., Tulisalo, E., and Soltanpour-Gargari, A.: Exchange of mercury between atmosphere and vegetation under contaminated conditions, Sci. Total Environ., 304, 169-174, https://doi.org/10.1016/S0048-9697(02)00566-1, 2003.

Lohila, A., Penttilä, T., Jortikka, S., Aalto, T., Anttila, P., Asmi, E., Aurela, M., Hatakka, J., Hellén, H., Henttonen, H., Hänninen, P., Kilkki, J., Kyllönen, K., Laurila, T., Lepistö, A., Lihavainen, H., Makkonen, U., Paatero, J., Rask, M., Sutinen, R., Tuovinen, J.-P., Vuorenmaa, J., and Viisanen, Y.: Preface to the special issue on integrated research of atmosphere, ecosystems and environment at Pallas, Boreal Environ. Res., 20, 431-454, 2015.

Loustau, D., Altimir, N., Barbaste, M., Gielen, B., Jiménez, S. M., Klumpp, K., Linder, S., Matteucci, G., Merbold, L., Op de Beeck, M., Soulé, P., Thimonier, A., Vincke, C., and Waldner, P.: Sampling and collecting foliage elements for the determination of the foliar nutrients in ICOS ecosystem stations, Int. Agrophys., 32, 665-676, https://doi.org/10.1515/intag-20170038, 2018.

Manceau, A., Wang, J., Rovezzi, M., Glatzel, P., and Feng, X.: Biogenesis of mercury-sulfur nanoparticles in plant leaves from atmospheric gaseous mercury, Environ. Sci. Technol., 52, 39353948, https://doi.org/10.1021/acs.est.7b05452, 2018.

Marshall, J. D. and Monserud, R. A.: Foliage height influences specific leaf area of three conifer species, Can. J. Forest Res., 33, 164-170, https://doi.org/10.1139/x02-158, 2003.

Matyssek, R., Reich, P., Oren, R., and Winner, W. E.: 9 - Response Mechanisms of Conifers to Air Pollutants, in: Eco- 
physiology of Coniferous Forests, edited by: Smith, W. K. and Hinckley, T. M., Academic Press, San Diego, 255-308, https://doi.org/10.1016/B978-0-08-092593-6.50014-1, 1995.

McLagan, D. S., Mitchell, C. P. J., Huang, H., Lei, Y. D., Cole, A. S., Steffen, A., Hung, H., and Wania, F.: A high-precision passive air sampler for gaseous mercury, Environ. Sci. Technol. Lett., 3, 24-29, https://doi.org/10.1021/acs.estlett.5b00319, 2016.

Merilo, E., Tulva, I., Räim, O., Kükit, A., Sellin, A., and Kull, O.: Changes in needle nitrogen partitioning and photosynthesis during 80 years of tree ontogeny in Picea abies, Trees, 23, 951-958, https://doi.org/10.1007/s00468-009-0337-9, 2009.

Millhollen, A. G., Gustin, M. S., and Obrist, D.: Foliar mercury accumulation and exchange for three tree species, Environ. Sci. Technol., 40, 6001-6006, https://doi.org/10.1021/es0609194, 2006.

Minamata Convention: DRAFT Report on the work of the ad hoc technical group on effectiveness evaluation, available at: http: //www.mercuryconvention.org/Portals/11/documents/meetings/ COP3/Effectiveness/EU-experts-comments-04Sep2019.pdf, (last access: 14 December 2020), 2019.

Monsi, M. and Saeki, T.: On the factor light in plant communities and its importance for matter production, Ann. Bot.-London, 95, 549-567, https://doi.org/10.1093/aob/mci052, 2004.

Morecroft, M. D. and Roberts, J. M.: Photosynthesis and stomatal conductance of mature canopy oak (Quercus robur) and sycamore (Acer pseudoplatanus) trees throughout the growing season, Funct. Ecol., 13, 332-342, https://doi.org/10.1046/j.1365-2435.1999.00327.x, 1999.

Navrátil, T., Shanley, J. B., Rohovec, J., Oulehle, F., Šimeček, M., Houška, J., and Cudlín, P.: Soil mercury distribution in adjacent coniferous and deciduous stands highly impacted by acid rain in the Ore Mountains, Czech Republic, Appl. Geochem., 75, 63-75, https://doi.org/10.1016/j.apgeochem.2016.10.005, 2016.

Navrátil, T., Nováková, T., Roll, M., Shanley, J. B., Kopáček, J., Rohovec, J., Kaňa, J., and Cudlín, P.: Decreasing litterfall mercury deposition in central European coniferous forests and effects of bark beetle infestation, Sci. Total Environ., 682, 213225, https://doi.org/10.1016/j.scitotenv.2019.05.093, 2019.

Niinemets, U., Ellsworth, D. S., Lukjanova, A., and Tobias, M.: Site fertility and the morphological and photosynthetic acclimation of Pinus sylvestris needles to light, Tree Physiol., 21, 1231-1244, https://doi.org/10.1093/treephys/21.17.1231, 2001.

NILU: EMEP manual for sampling and chemical analysis, EMEP/CCC-Report, 1/95, available at: https://projects.nilu.no/ ccc/manual/download/cccr1-95rev.pdf (last accessed 14 December 2020), 2001.

Obrist, D.: Atmospheric mercury pollution due to losses of terrestrial carbon pools?, Biogeochemistry, 85, 119-123, https://doi.org/10.1007/s10533-007-9108-0, 2007.

Obrist, D., Johnson, D. W., Lindberg, S. E., Luo, Y., Hararuk, O., Bracho, R., Battles, J. J., Dail, D. B., Edmonds, R. L., Monson, R. K., Ollinger, S. V., Pallardy, S. G., Pregitzer, K. S., and Todd, D. E.: Mercury distribution across 14 US forests, Part I: spatial patterns of concentrations in biomass, litter, and soils, Environ. Sci. Technol., 45, 3974-3981, https://doi.org/10.1021/es104384m, 2011.

Obrist, D., Johnson, D. W., and Edmonds, R. L.: Effects of vegetation type on mercury concentrations and pools in two adjacent coniferous and deciduous forests, J. Plant Nutr. Soil Sc., 175, 68-77, https://doi.org/10.1002/jpln.201000415, 2012.

Obrist, D., Pokharel, A. K., and Moore, C.: Vertical profile measurements of soil air suggest immobilization of gaseous elemental mercury in mineral soil, Environ. Sci. Technol., 48, 2242-2252, https://doi.org/10.1021/es4048297, 2014.

Obrist, D., Agnan, Y., Jiskra, M., Olson, C. L., Colegrove, D. P., Hueber, J., Moore, C. W., Sonke, J. E., and Helmig, D.: Tundra uptake of atmospheric elemental mercury drives Arctic mercury pollution, Nature, 547, 201-204, https://doi.org/10.1038/nature22997, 2017.

Obrist, D., Kirk, J. L., Zhang, L., Sunderland, E. M., Jiskra, M., and Selin, N. E.: A review of global environmental mercury processes in response to human and natural perturbations: Changes of emissions, climate, and land use, Ambio, 47, 116140, https://doi.org/10.1007/s13280-017-1004-9, 2018.

Ollerova, H., Maruskova, A., Kontrisova, O., and Pliestikova, L.: Mercury accumulation in Picea abies (L.) Karst. needles with regard to needle age, Pol. J. Environ. Stud., 19, 1401-1404, 2010.

Op de Beeck, M., Gielen, B., Jonckheere, I., Samson, R., Janssens, I. A., and Ceulemans, R.: Needle age-related and seasonal photosynthetic capacity variation is negligible for modelling yearly gas exchange of a sparse temperate Scots pine forest, Biogeosciences, 7, 199-215, https://doi.org/10.5194/bg-7-1992010, 2010.

Pacyna, J. M., Pacyna, E. G., and Aas, W.: Changes of emissions and atmospheric deposition of mercury, lead, and cadmium, Atmos. Environ., 43, 117-127, https://doi.org/10.1016/j.atmosenv.2008.09.066, 2009.

Pokharel, A. K. and Obrist, D.: Fate of mercury in tree litter during decomposition, Biogeosciences, 8, 2507-2521, https://doi.org/10.5194/bg-8-2507-2011, 2011.

Poole, I., Weyers, J. D. B., Lawson, T., and Raven, J. A.: Variations in stomatal density and index: implications for palaeoclimatic reconstructions, Plant Cell Environ., 19, 705-712, https://doi.org/10.1111/j.1365-3040.1996.tb00405.x, 1996.

Prestbo, E. M. and Gay, D. A.: Wet deposition of mercury in the US and Canada, 1996-2005: Results and analysis of the NADP mercury deposition network (MDN), Atmos. Environ., 43, 42234233, https://doi.org/10.1016/j.atmosenv.2009.05.028, 2009.

Rasmussen, P. E., Mierle, G., and Nriagu, J. O.: The analysis of vegetation for total mercury, Water Air Soil Poll., 56, 379-390, https://doi.org/10.1007/BF00342285, 1991.

Rautio, P., Fürst, A., Stefan, K., Raitio, H., and Bartels, U.: UNECE ICP Forests Programme Co-ordinating Centre: Manual on methods and criteria for harmonized sampling, assessment, monitoring and analysis of the effects of air pollution on forests, Part XII: Sampling and analysis of needles and leaves, Thünen Institute of Forest Ecosystems, Eberswalde, Germany, available at: https://www.icp-forests.org/pdf/manual/2016/ICP Manual_2017_01_part12.pdf (last access: 14 December 2020), 2016.

Rea, A. W., Keeler, G. J., and Scherbatskoy, T.: The deposition of mercury in throughfall and litterfall in the Lake Champlain Watershed: A short-term study, Atmos. Environ., 30, 3257-3263, https://doi.org/10.1016/1352-2310(96)00087-8, 1996.

Rea, A. W., Lindberg, S. E., and Keeler, G. J.: Dry deposition and foliar leaching of mercury and selected trace elements in 
deciduous forest throughfall, Atmos. Environ., 35, 3453-3462, https://doi.org/10.1016/S1352-2310(01)00133-9, 2001.

Rea, A. W., Lindberg, S. E., Scherbatskoy, T., and Keeler, G. J.: Mercury accumulation in foliage over time in two northern mixed-hardwood forests, Water Air Soil Poll., 133, 49-67, 2002.

Reich, P. B., Walters, M. B., and Ellsworth, D. S.: From tropics to tundra: Global convergence in plant functioning, P. Natl. Acad. Sci. USA, 94, 13730-13734, https://doi.org/10.1073/pnas.94.25.13730, 1997.

Risch, M. R., DeWild, J. F., Krabbenhoft, D. P., Kolka, R. K., and Zhang, L.: Litterfall mercury dry deposition in the eastern USA, Environ. Pollut., 161, 284-290, https://doi.org/10.1016/j.envpol.2011.06.005, 2012.

Risch, M. R., DeWild, J. F., Gay, D. A., Zhang, L., Boyer, E. W., and Krabbenhoft, D. P.: Atmospheric mercury deposition to forests in the eastern USA, Environ. Pollut., 228, 8-18, https://doi.org/10.1016/j.envpol.2017.05.004, 2017.

Robakowski, P. and Bielinis, E.: Needle age dependence of photosynthesis along a light gradient within an Abies alba crown, Acta Physiol. Plant., 39, 83, https://doi.org/10.1007/s11738-0172376-y, 2017.

Rötzer, T. and Chmielewski, F.: Phenological maps of Europe, Clim. Res., 18, 249-257, https://doi.org/10.3354/cr018249, 2001.

Rutter, A. P., Schauer, J. J., Shafer, M. M., Creswell, J. E., Olson, M. R., Robinson, M., Collins, R. M., Parman, A. M., Katzman, T. L., and Mallek, J. L.: Dry deposition of gaseous elemental mercury to plants and soils using mercury stable isotopes in a controlled environment, Atmos. Environ., 45, 848855, https://doi.org/10.1016/j.atmosenv.2010.11.025, 2011.

Saiz-Lopez, A., Sitkiewicz, S. P., Roca-Sanjuán, D., Oliva-Enrich, J. M., Dávalos, J. Z., Notario, R., Jiskra, M., Xu, Y., Wang, F., Thackray, C. P., Sunderland, E. M., Jacob, D. J., Travnikov, O., Cuevas, C. A., Acuña, A. U., Rivero, D., Plane, J. M. C., Kinnison, D. E., and Sonke, J. E.: Photoreduction of gaseous oxidized mercury changes global atmospheric mercury speciation, transport and deposition, Nat. Commun., 9, 4796, https://doi.org/10.1038/s41467-018-07075-3, 2018.

Schleyer, R., Bieber, E., and Wallasch, M.: Das Luftmessnetz des Umweltbundesamtes, UBA German Federal Environment Agency, Dessau-Roßlau, available at: https://www.umweltbundesamt.de/sites/default/files/medien/ 378/publikationen/das_luftmessnetz_des_umweltbundesamtes_ bf_0.pdf (last access: 14 December 2020) 2013 (in German).

Schuldt, B., Buras, A., Arend, M., Vitasse, Y., Beierkuhnlein, C., Damm, A., Gharun, M., Grams, T. E. E., Hauck, M., Hajek, P., Hartmann, H., Hiltbrunner, E., Hoch, G., Holloway-Phillips, M., Körner, C., Larysch, E., Lübbe, T., Nelson, D. B., Rammig, A., Rigling, A., Rose, L., Ruehr, N. K., Schumann, K., Weiser, F., Werner, C., Wohlgemuth, T., Zang, C. S., and Kahmen, A.: A first assessment of the impact of the extreme 2018 summer drought on Central European forests, Basic Appl. Ecol., 45, 86103, https://doi.org/10.1016/j.baae.2020.04.003, 2020.

Schulze, E. D.: Carbon dioxide and water vapor exchange in response to drought in the atmosphere and in the soil, Ann. Rev. Plant Physio., 37, 247-274, 1986.

Sharma, R. P., Vacek, Z., and Vacek, S.: Individual tree crown width models for Norway spruce and European beech in Czech Republic, Forest Ecol. Manag., 366, 208-220, https://doi.org/10.1016/j.foreco.2016.01.040, 2016.

Sonnewald, U.: Physiology of Development, in: Strasburger's Plant Sciences, Springer, Berlin, Heidelberg, Germany, 411-530, https://doi.org/10.1007/978-3-642-15518-5_6, 2013.

Sprovieri, F., Pirrone, N., Bencardino, M., D'Amore, F., Angot, H., Barbante, C., Brunke, E.-G., Arcega-Cabrera, F., Cairns, W., Comero, S., Diéguez, M. D. C., Dommergue, A., Ebinghaus, R., Feng, X. B., Fu, X., Garcia, P. E., Gawlik, B. M., Hageström, U., Hansson, K., Horvat, M., Kotnik, J., Labuschagne, C., Magand, O., Martin, L., Mashyanov, N., Mkololo, T., Munthe, J., Obolkin, V., Ramirez Islas, M., Sena, F., Somerset, V., Spandow, P., Vardè, M., Walters, C., Wängberg, I., Weigelt, A., Yang, X., and Zhang, H.: Five-year records of mercury wet deposition flux at GMOS sites in the Northern and Southern hemispheres, Atmos. Chem. Phys., 17, 2689-2708, https://doi.org/10.5194/acp17-2689-2017, 2017.

St. Louis, V. L., Rudd, J. W. M., Kelly, C. A., Hall, B. D., Rolfhus, K. R., Scott, K. J., Lindberg, S. E., and Dong, W.: Importance of the forest canopy to fluxes of methyl mercury and total mercury to boreal ecosystems, Environ. Sci. Technol., 35, 3089-3098, https://doi.org/10.1021/es001924p, 2001.

Stamenkovic, J. and Gustin, M. S.: Nonstomatal versus Stomatal Uptake of Atmospheric Mercury, Environ. Sci. Technol., 43, 1367-1372, https://doi.org/10.1021/es801583a, 2009.

Stancioiu, P. T. and O'Hara, K. L.: Morphological plasticity of regeneration subject to different levels of canopy cover in mixedspecies, multiaged forests of the Romanian Carpathians, Trees, 20, 196-209, https://doi.org/10.1007/s00468-005-0026-2, 2006.

Tahvanainen, T. and Forss, E.: Individual tree models for the crown biomass distribution of Scots pine, Norway spruce and birch in Finland, Forest Ecol. Manag., 255, 455-467, https://doi.org/10.1016/j.foreco.2007.09.035, 2008.

Teixeira, D. C., Montezuma, R. C., Oliveira, R. R. and SilvaFilho, E. V.: Litterfall mercury deposition in Atlantic forest ecosystem from SE - Brazil, Environ. Pollut., 164, 11-15, https://doi.org/10.1016/j.envpol.2011.10.032, 2012.

Temesgen, H., LeMay, V., and Mitchell, S. J.: Tree crown ratio models for multi-species and multi-layered stands of southeastern British Columbia, Forest. Chron., 81, 133-141, https://doi.org/10.5558/tfc81133-1, 2005.

Tørseth, K., Aas, W., Breivik, K., Fjæraa, A. M., Fiebig, M., Hjellbrekke, A. G., Lund Myhre, C., Solberg, S., and Yttri, K. E.: Introduction to the European Monitoring and Evaluation Programme (EMEP) and observed atmospheric composition change during 1972-2009, Atmos. Chem. Phys., 12, 5447-5481, https://doi.org/10.5194/acp-12-5447-2012, 2012.

Tyrrell, M. L., Ross, J., and Kelty, M.: Carbon dynamics in the Temperate Forest, in: Managing Forest Carbon in a Changing Climate, edited by: Ashton, M. S., Tyrrell, M. L., Spalding, D., and Gentry, B., Springer, Dordrecht, the Netherlands, 77-107, 2012

UBA: Qualitätssicherungshandbuch des UBA Messnetzes, Texte 28-04, German Federal Environment Agency) Berlin, 536 pp., available at: https://www.umweltbundesamt.de/sites/default/ files/medien/publikation/long/2766.pdf (last access: 14 December 2020) 2004 (in German).

UN Environment: Global Mercury Assessment Report 2018, UN Environmental Programme, Chemicals and Health Branch Geneva, Switzerland, available at: https://wedocs.unep.org/ 
bitstream/handle/20.500.11822/27579/GMA2018.pdf, last access: 2 October 2019.

Wang, X., Bao, Z., Lin, C.-J., Yuan, W., and Feng, X.: Assessment of global mercury deposition through litterfall, Environ. Sci. Technol., 50, 8548-8557, https://doi.org/10.1021/acs.est.5b06351, 2016.

Wängberg, I. and Munthe, J.: Atmospheric mercury in Sweden, Northern Finland and Northern Europe, Results from national monitoring and European research, IVL Swedish Environmental Research Institute report, available at: https://www.ivl.se/download/18.34244ba71728fcb3f3f5ee/ 1591704288589/B1399.pdf (last access: 14 December 2020), 2001.

Wängberg, I., Munthe, J., Berg, T., Ebinghaus, R., Kock, H. H., Temme, C., Bieber, E., Spain, T. G., and Stolk, A.: Trends in air concentration and deposition of mercury in the coastal environment of the North Sea Area, Atmos. Environ., 41, 2612-2619, https://doi.org/10.1016/j.atmosenv.2006.11.024, 2007.

Wängberg, I., Nerentorp Mastromonaco, M. G., Munthe, J., and Gårdfeldt, K.: Airborne mercury species at the Råö background monitoring site in Sweden: distribution of mercury as an effect of long-range transport, Atmos. Chem. Phys., 16, 13379-13387, https://doi.org/10.5194/acp-16-13379-2016, 2016.

Warren, C. R.: Why does photosynthesis decrease with needle age in Pinus pinaster?, Trees, 20, 157-164, https://doi.org/10.1007/s00468-005-0021-7, 2006.

Weiss-Penzias, P. S., Gay, D. A., Brigham, M. E., Parsons, M. T., Gustin, M. S., and ter Schure, A.: Trends in mercury wet deposition and mercury air concentrations across the US and Canada, Sci. Total Environ., 568, 546-556, https://doi.org/10.1016/j.scitotenv.2016.01.061, 2016.

Wieser, G. and Tausz, M.: Trees at their Upper Limit: Treelife Limitation at the Alpine Timberline, Springer, Dordrecht, Netherlands, ISBN 978-1-4020-5074-9, 2007.

Wohlgemuth, L.: Dataset to Publication: A bottom-up quantification of foliar mercury uptake fluxes across Europe, Zenodo, https://doi.org/10.5281/zenodo.3957873, 2020.

Wright, I. J., Reich, P. B., Westoby, M., Ackerly, D. D., Baruch, Z., Bongers, F., Cavender-Bares, J., Chapin, T., Cornelissen, J. H. C., Diemer, M., Flexas, J., Garnier, E., Groom, P. K., Gulias, J., Hikosaka, K., Lamont, B. B., Lee, T., Lee, W., Lusk, C., Midgley, J. J., Navas, M.-L., Niinemets, Ü., Oleksyn, J., Osada, N., Poorter, H., Poot, P., Prior, L., Pyankov, V. I., Roumet, C., Thomas, S. C., Tjoelker, M. G., Veneklaas, E. J., and Villar, R.: The worldwide leaf economics spectrum, Nature, 428, 821-827, https://doi.org/10.1038/nature02403, 2004.
Wright, L. P., Zhang, L., and Marsik, F. J.: Overview of mercury dry deposition, litterfall, and throughfall studies, Atmos. Chem. Phys., 16, 13399-13416, https://doi.org/10.5194/acp-16-133992016, 2016.

Xiao, C.-W., Janssens, I. A., Curiel Yuste, J., and Ceulemans, R.: Variation of specific leaf area and upscaling to leaf area index in mature Scots pine, Trees, 20, 304, https://doi.org/10.1007/s00468-005-0039-x, 2006.

Yang, Y., Yanai, R. D., Montesdeoca, M., and Driscoll, C. T.: Measuring mercury in wood: challenging but important, Int. J. Environ. An. Ch., 97, 456-467, https://doi.org/10.1080/03067319.2017.1324852, 2017.

Yuan, W., Sommar, J., Lin, C.-J., Wang, X., Li, K., Liu, Y., Zhang, H., Lu, Z., Wu, C., and Feng, X.: Stable isotope evidence shows re-emission of elemental mercury vapor occurring after reductive loss from foliage, Environ. Sci. Technol., 53, 651-660, https://doi.org/10.1021/acs.est.8b04865, 2019.

Zhang, L., Wright, L. P., and Blanchard, P.: A review of current knowledge concerning dry deposition of atmospheric mercury, Atmos. Environ., 43, 5853-5864, https://doi.org/10.1016/j.atmosenv.2009.08.019, 2009.

Zhang, L., Wu, Z., Cheng, I., Wright, L. P., Olson, M. L., Gay, D. A., Risch, M. R., Brooks, S., Castro, M. S., Conley, G. D., Edgerton, E. S., Holsen, T. M., Luke, W., Tordon, R., and Weiss-Penzias, P.: The estimated six-year mercury dry deposition across North America, Environ. Sci. Technol., 50, 12864-12873, https://doi.org/10.1021/acs.est.6b04276, 2016.

Zheng, W., Obrist, D., Weis, D., and Bergquist, B. A.: Mercury isotope compositions across North American forests, Global Biogeochem. Cy., 30, 1475-1492, https://doi.org/10.1002/2015GB005323, 2016. 